\title{
Structure, Dynamics, and Energetics of the Primary Photochemistry of Photosystem II of OXYGenic Photosynthesis
}

\author{
Bruce A. Diner ${ }^{1}$ and Fabrice Rappaport ${ }^{2}$ \\ ${ }^{I} C R \& D$, Experimental Station, E. I. du Pont de Nemours \& Co., Wilmington, \\ Delaware 19880-0173; e-mail: Bruce.A.Diner@usa.dupont.com \\ ${ }^{2}$ Service de Photosynthèse/UPR-CNRS 1261, Institut de Biologie Physico-Chimique, \\ 75005 Paris, France; e-mail: rappaport@ibpc.fr
}

Key Words P680, reaction center, primary charge separation, chlorophyll, pheophytin

Abstract Recent progress in two-dimensional and three-dimensional electron and X-ray crystallography of Photosystem II (PSII) core complexes has led to major advances in the structural definition of this integral membrane protein complex. Despite the overall structural and kinetic similarity of the PSII reaction centers to their purple nonsulfur photosynthetic bacterial homologues, the different cofactors and subtle differences in their spatial arrangement result in significant differences in the energetics and mechanism of primary charge separation. In this review we discuss some of the recent spectroscopic, structural, and mutagenic work on the primary and secondary electron transfer reactions in PSII, stressing what is experimentally novel, what new insights have appeared, and where questions of interpretation remain.

\section{CONTENTS}

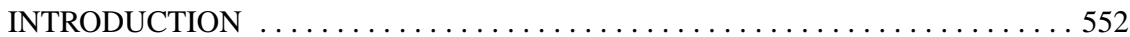

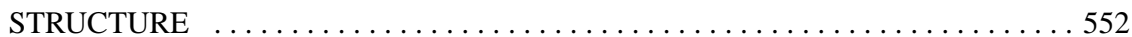

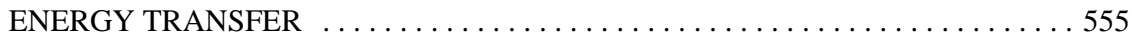

COMPARISON WITH BACTERIAL REACTION CENTERS . . . . . . . . . . 557

SPECTRA OF PSII REACTION CENTER CHLORINS $\ldots \ldots \ldots \ldots \ldots \ldots \ldots \ldots 58$

$\mathrm{P}_{\mathrm{A}}$, the Primary Site for $\mathrm{P}^{+}$Cation Localization $\ldots \ldots \ldots \ldots \ldots \ldots \ldots \ldots \ldots$

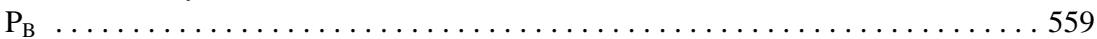

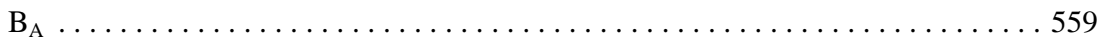

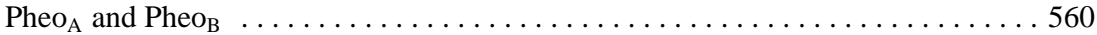

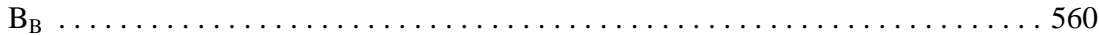

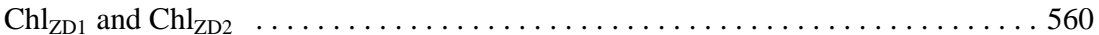

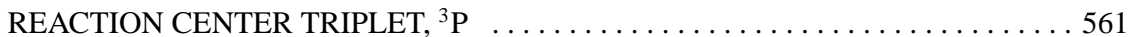

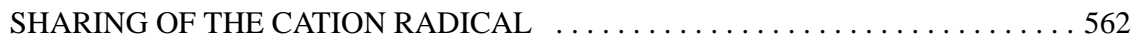

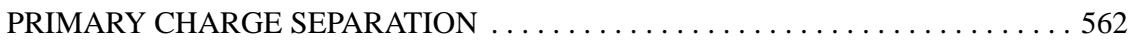

DONOR-SIDE SECONDARY ELECTRON TRANSFER $\ldots \ldots \ldots \ldots \ldots \ldots \ldots 6$ 
RETENTION OF TYROSINE PHENOLIC

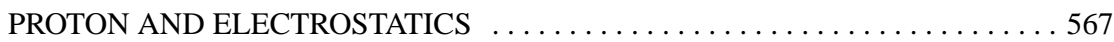

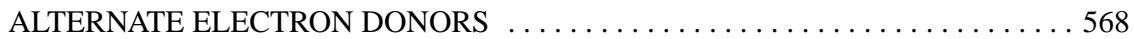

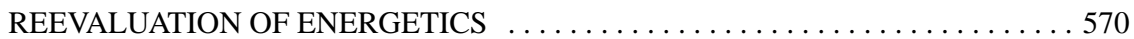

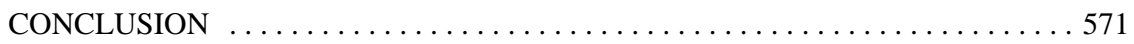

\section{INTRODUCTION}

In the past few years there have been a considerable number of advances at the spectroscopic, biochemical, and structural level that have improved our understanding of structure/function relationships in the Photosystem II (PSII) reaction center. We attempt to integrate here many of these findings as they relate to primary and secondary electron transfer, stressing what is new and what issues still remain unresolved. We refer the reader to a number of excellent review articles $(22,24,27,46,88,90,133)$ that cover in more detail some of the older data or are more focussed in covering a subset of the topics addressed here.

\section{STRUCTURE}

Really spectacular progress has been made very recently in the description of the physical structure of the PSII reaction center and core complexes. The term reaction center has been used to describe a biochemically isolated entity comprised of polypeptides D1 and D2 (PsbA and PsbD, respectively, plus redox cofactors), cytochrome $\mathrm{b}_{559}$ (PsbE and F, plus heme) and PsbI (56a, 77a). In this review, unless otherwise indicated, this term refers only to the D1/D2 complex including the associated cofactors. The PSII core complex, also biochemically isolated, contains up to 25 different integral membrane and extrinsic polypeptide subunits (50), including those of the biochemically isolated reaction center and chlorophyll-protein complexes CP43 (PsbC) and CP47 (PsbB). Beginning with an appreciation of the structural and functional homologies between the reaction centers of PSII and those of the purple nonsulfur photosynthetic bacteria $(75,125)$, increasingly detailed models have been proposed for the arrangement of the prosthetic groups and of the D1 (L) and D2 (M) subunits that coordinate them $(97,112,148)$. After many years of trying to do protein crystallography, investigators have had major successes recently that are allowing them to place the structural models on a much firmer footing. First, a spinach subcore complex containing the reaction center and CP47 formed, upon detergent dialysis, two-dimensional crystals (91) that yielded an 8 - $\AA$ structure (92), following image processing of electron micrographs. This structure has now been refined to $6 \AA$ (90). More recently, three-dimensional crystals of dimeric $\mathrm{O}_{2}$-evolving PSII core complexes from Synechococcus elongatus have, in a remarkable advance, yielded a structure with $3.8-\AA ̊$ resolution (149). Although the resolution is still too low to resolve the side chains of the amino acid residues, most of the chromophores, the $\alpha$-helices, the $\beta$-sheets, and the Mn cluster have been 
localized with good precision (Figure 1). The overall protein complex extends well outside the membrane, $10 \AA$ on the stromal side and $55 \AA$ on the lumenal side. A band that is $40 \AA$ thick is considered to be within the membrane. At least 17 subunits are present, 14 of which are integral membrane polypeptides, contributing 36 transmembrane $\alpha$-helices. A total of 35 chlorophylls (Chls) have been identified, with 16 assigned to polypeptide CP47, 13 to polypeptide CP43, and 3 each to polypeptides D1 and D2 (137). Two pheophytins (Pheos) are associated with the D1-D2 complex, which forms the heart of the reaction center. These chlorins are arranged in a pseudo- $\mathrm{C}_{2}$-symmetrical fashion around the nonheme iron, as are the CP47 and D2 polypeptides on one side and CP43 and D1 on the other. The symmetry is broken by the cytochrome $\mathrm{b}_{559}$ heme on the stromal side of the complex and coordinated by PsbE and PsbF, which are located near the D2 subunit but $27 \AA$ from $\mathrm{Chl}_{\mathrm{ZD} 2}$ (see below); by the Mn cluster associated with the lumenal side of D1 and located $15 \AA$ from the pseudo- $\mathrm{C}_{2}$-symmetry axis; and by cytochrome $c_{550}$ and $\mathrm{PsbO}$, which are extrinsically associated with the lumenal side of CP43 and of D1, respectively.

Analysis of this structure as well as that at the primary, amino acid level have indicated significant differences with the reaction centers of Rhodopseudomonas viridis and Rhodobacter sphaeroides. The central reaction center chlorins (Figure 1) are designated as belonging to the A or B branch of the reaction center, the presumed electron transfer active and inactive branches, respectively. The special pair chlorophylls, $\mathrm{P}_{\mathrm{A}}\left(\mathrm{P}_{\mathrm{D} 1}\right)$ and $\mathrm{P}_{\mathrm{B}}\left(\mathrm{P}_{\mathrm{D} 2}\right)$ located on the lumenal side of the complex and implicated in primary charge separation (see below), have parallel ring planes $5 \AA$ apart and are $10 \AA$ apart center to center $(91,149)$. These are more widely separated (Figure 2) than the special pair bacteriochlorophylls (Bchlorophylls) in the bacterial reaction centers where the respective ring plane separation and center to center distance are $3.5 \AA$ and 7.4-7.6 $\AA$ [e.g., Reference (36)]. This wider separation in PSII greatly weakens the excitonic coupling that characterizes the bacterial reaction center homologues. This difference has important consequences for excitation energy localization within the reaction center (see below). Two monomeric chlorophylls, $\mathrm{B}_{\mathrm{A}}$ and $\mathrm{B}_{\mathrm{B}}$, located $9.8 \AA$ and $10 \AA$, respectively, center to center from $\mathrm{P}_{\mathrm{A}}$ and $\mathrm{P}_{\mathrm{B}}$, are inclined at a $30^{\circ}$ angle with respect to the membrane plane as are their Bchlorophyll homologues in the bacterial reaction centers. The homologous histidines that coordinate these Bchlorophylls in the bacterial reaction centers are missing in PSII. $\mathrm{Pheo}_{\mathrm{A}}$ and $\mathrm{Pheo}_{\mathrm{B}}$ are located at $10.7 \AA$ and $10.6 \AA$, respectively, (center to center) toward the stromal side from $B_{A}$ and $\mathrm{B}_{\mathrm{B}}$, with their head groups perpendicular to the membrane plane. The primary quinone electron acceptor, $\mathrm{Q}_{\mathrm{A}}$, is located an additional $12.0 \AA$ (center to center) toward the stromal side from $\mathrm{Pheo}_{\mathrm{A}}$ and $10.5 \AA$ from the nonheme iron. Electron transfer in the bacterial reaction centers originates from the $\mathrm{P}_{\mathrm{A}} / \mathrm{P}_{\mathrm{B}}$ special pair in its lowest excited singlet state to $\mathrm{B}_{\mathrm{A}}$ then to $\mathrm{Pheo}_{\mathrm{A}}$ and ultimately to $\mathrm{Q}_{\mathrm{A}}$ [for review see Reference (147)]. Despite the presence of homologous redox components in PSII, kinetic deconvolution of energy transfer and primary charge separation in PSII is complicated by the spectral congestion that exists within its reaction center 


\section{Center-to-center distances $(\AA)$}

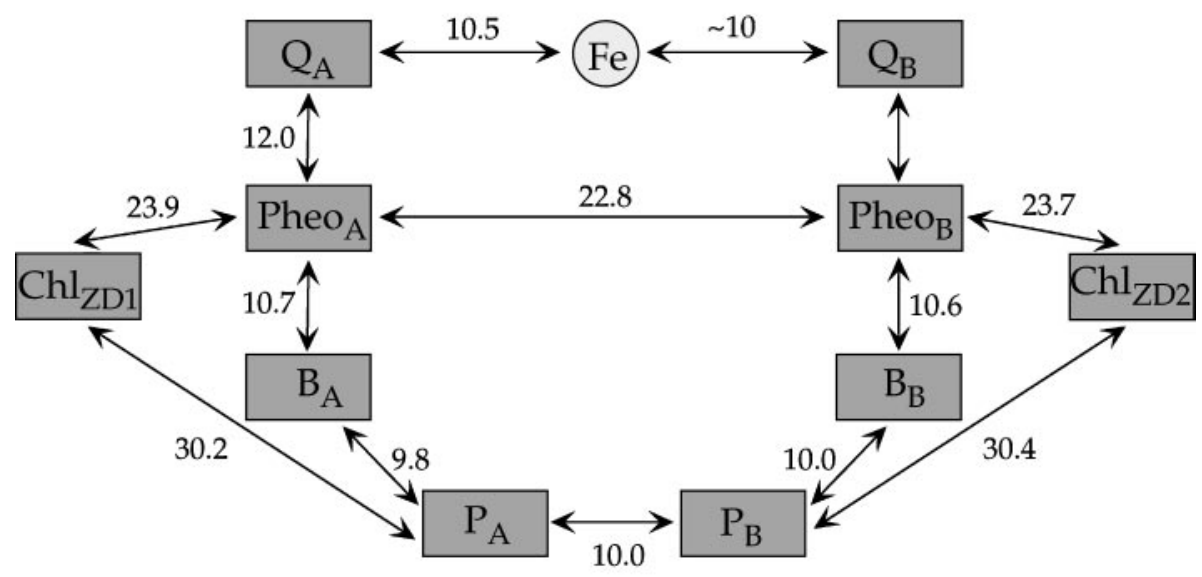

PSII - Synechococcus elongatus (149)

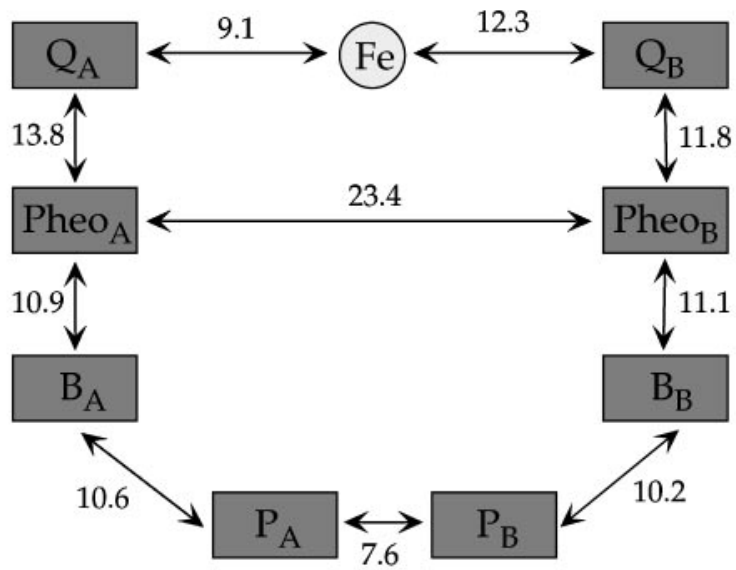

BRC - Rhodobacter sphaeroides (36)

Figure 2 The center to center distances in $\AA$ between the cofactors of the Synechococcus elongatus PSII reaction centers (149) and of the Rb. sphaeroides reaction centers (36). Adapted from (36). 
(see below). An additional symmetrically localized pair of chlorophylls, for which there is no homologue in the bacterial reaction center, $\mathrm{Chl}_{\mathrm{ZD} 1}$ and $\mathrm{Chl}_{\mathrm{ZD} 2}$, is located at $30.2 \AA$ and $30.4 \AA$, respectively, from $\mathrm{P}_{\mathrm{A}}$ and $\mathrm{P}_{\mathrm{B}}$. One or both of these can be oxidized in a low quantum yield process (see below) that may regulate PSII charge separation in a nonphotochemical quenching process [e.g., Reference (106)].

The current level of resolution of the PSII crystal structure permits only a description of the $\mathrm{C} \alpha$ trace of the most-ordered $\alpha$-helical and $\beta$-sheet regions of the polypeptides that comprise the PSII core complex. The identity and orientation of the amino acid side chains remain unknown. Despite this lack of definition, there are a number of residues, some of which are bacterial reaction center homologues, that have been identified by site-directed mutations coupled with spectroscopic analysis as being ligands to prosthetic groups. These are discussed below as we describe each of the redox active components of the PSII reaction center.

\section{ENERGY TRANSFER}

New structural data have permitted the localization of 37 of the chlorin rings (35 chlorophylls and two pheophytins) $(137,149)$. The position (within $1 \AA$ ) and orientation (within $10^{\circ}$ ) of the ring planes are known with considerable accuracy. Although the orientation of the transition dipoles cannot be deduced from the crystal structure, these are to some extent known from linear dichroism and photoselection experiments. This structural information has promoted renewed interest in modeling of the kinetics of energy transfer from the antenna to the reaction center. There appear to be two camps regarding this issue. In one of these (Figure 3), the Reversible Radical Pair Model $(3,12,21,102)$, there is rapid equilibration of the excitation energy between the antenna and the reaction center $[\tau \leq 15 \mathrm{ps}$; e.g.,

\section{Reversible Radical Pair Model}

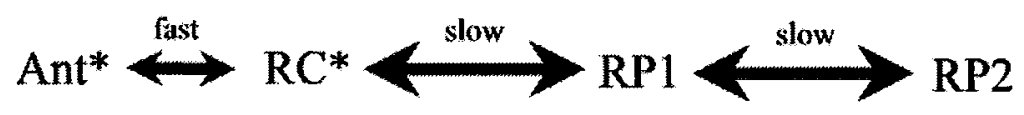

\section{Energy Transfer to the Trap Limited Model}

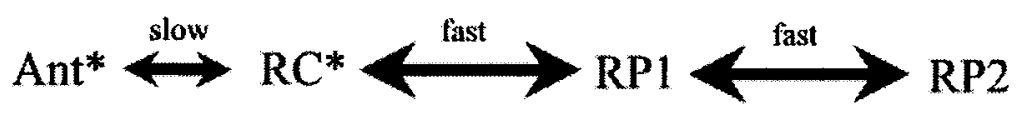

Figure 3 Two contrasting models for the kinetic limitation of primary charge separation in PSII. In the upper model, the rate is limited by electron transfer within the reaction center. In the lower model, the rate is limited by energy transfer to the reaction center. 
(21)]. The latter is a shallow trap, and charge separation is trap limited. Barter et al. (3) have recently provided additional support for this model by showing that the effect of the antenna size on the $\mathrm{Chl}^{*}$ singlet state lifetime could be well simulated by a three-state model [(AntennaRC) $)^{*} \leftrightarrow \mathrm{RP} 1 \leftrightarrow \mathrm{RP} 2$ ] in which the excitation energy is rapidly equilibrated between the antenna and reaction center, and two radical pair states (RP1 and RP2) are involved in the slower, two-stage trapping process. The lifetime of the singlet excited state increases with antenna size, ranging from reaction centers ( 8 chlorin pigments) up to PSII membrane fragments from spinach (BBY, $\sim 250$ chlorin pigments) (5).

In a contrasting model (Figure 3), equilibration of light energy within the antenna complexes $[\tau<5$ ps $(21,137)]$ and within the reaction center $[\tau \leq 400 \mathrm{fs}$, $(35,73)]$ is considered to be rapid, but energy transfer between the antenna and the reaction center is slow and rate limiting. Based on careful examination of the PSII X-ray crystal structure, Vasil'ev et al. (137) concluded that two chlorophylls, C12 and $\mathrm{C} 30$ of $\mathrm{CP} 43$ and $\mathrm{CP} 47$, respectively, are the core antenna pigments that are responsible for $50 \%$ of energy transfer to the reaction center. These authors concluded, however, that the distance and orientation of these pigments with respect to the reaction center pigments would put energy transfer to the reaction center in the 100 ps range, making energy transfer to the center rate limiting for charge separation. This may be a common feature in photosynthesis as rate limitation by energy transfer to the reaction center has also been observed in $R b$. sphaeroides (4) and in PSI (127) [for review see (133)]. An additional conclusion of Vasil'ev et al. (137) is that a lower limit for the intrinsic rate of charge separation in PSII is $(0.7 \mathrm{ps})^{-1}$, a rate consistent with a rapid component for charge separation upon direct excitation of P680 as reported by Groot et al. (47) ( $\tau=0.4$ ps at $240 \mathrm{~K})$. This rate is substantially faster than most reports of charge separation, which range from 1-20 ps for PSII $(32,44,61,95,103,139)$ and for bacterial reaction centers $(38,133)$. Groot et al. (47) suggest that even within the PSII reaction center there could be kinetic components for energy transfer (e.g., between the active and inactive branches) that could be rate limiting for charge separation. Multiple radical pair states, inhomogeneous broadening, and protein relaxation all may be contributing to the kinetic heterogeneity observed for charge separation in PSII (see below). The two peripheral reaction center chlorophylls, $\mathrm{Chl}_{\mathrm{ZD} 1}$ and $\mathrm{Chl}_{\mathrm{ZD} 2}$, which had been proposed to be the main conduits for energy transfer into the center $(70,136)$, have orientations and positions that make for weaker coupling to the antenna and reaction center than do $\mathrm{C} 12$ and $\mathrm{C} 30$. This conclusion is consistent with measurements of Schelvis et al. (103) in which a 20-30 ps component for charge separation was attributed to a rate limitation by energy transfer from $\mathrm{Chl}_{\mathrm{ZD} 1}$ and $\mathrm{Chl}_{\mathrm{ZD} 2}$ [see also (136)].

The Energy Transfer To The Trap Limited Model should show a rate of charge separation that is only weakly dependent on antenna size and on the intrinsic rate of charge separation within the reaction center in PSII preparations containing CP43 and $\mathrm{CP} 47$, i.e., preserving the integrity of the rate-limiting step. In the $\mathrm{D}_{1} \mathrm{D}_{2}$ cyt $b_{559}$ PSII reaction centers that lack these two subunits, the observed rate should, in this model, more closely reflect the intrinsic rate of charge separation. At variance 
with this expectation, Barter et al. (3) found a rather monotonic dependence of the singlet excited state lifetime upon the antenna size. It could be argued, however, that the $D_{1} D_{2}$ cyt $b_{559}$ PSII reaction centers, the smallest photoactive complexes, were missing $\mathrm{Q}_{\mathrm{A}}$, whereas the larger ones had $\mathrm{Q}_{\mathrm{A}}$ reduced. This difference could distort the apparent dependence of the excited state lifetime on antenna size. Indeed, the redox state of $\mathrm{Q}_{\mathrm{A}}$ could influence, likely via electrostatic effects, the singlet state lifetimes independent of antenna size. It has been observed that the redox state of the quinone has a large influence on the rise $(95,102)$ kinetics of primary radical pair formation. Gibasiewicz et al. (41), however, showed that the kinetics of radical pair formation as detected by a photovoltaic method were largely independent of the redox state of $\mathrm{Q}_{\mathrm{A}}$, although the decay was greatly accelerated by $\mathrm{Q}_{\mathrm{A}}^{-}$as opposed to $\mathrm{Q}_{\mathrm{A}}$ or $\mathrm{Q}_{\mathrm{A}} \mathrm{H}_{2}$. This issue remains to be resolved. Ways in which the two models of Figure 3 might begin to overlap could include the discovery of additional chlorophylls that have not yet been resolved in the 3.8 - $\AA$ crystal structure that might speed antenna-center excitation equilibration or, as Groot et al. (47) suggest, there might be energy transfer rate limitations even within the reaction center.

\section{COMPARISON WITH BACTERIAL REACTION CENTERS}

Primary charge separation in the reaction centers of the purple photosynthetic bacteria is initiated by the excitation of the special pair Bchlorophylls, $\mathrm{P}_{\mathrm{A}}$ and $\mathrm{P}_{\mathrm{B}}$, following energy transfer from the light-harvesting complexes. These $\mathrm{P}_{\mathrm{A}}$ and $P_{B}$ are located close to each other (36) (see above) (Figures 1 and 2) and are excitonically coupled $\left(500-1000 \mathrm{~cm}^{-1}\right)$, thereby constituting a long wavelength trap for the reaction center excitation energy (e.g., $870 \mathrm{~nm}$ in Rb. sphaeroides) (147). The splitting between the special pair Bchlorophylls $\left(\mathrm{P}_{\mathrm{A}} / \mathrm{P}_{\mathrm{B}}\right)$ and the accessory Bchlorophylls $\left(\mathrm{B}_{\mathrm{A}}\right.$ and $\mathrm{B}_{\mathrm{B}}$ ) is $\sim 1000 \mathrm{~cm}^{-1}$ and between the special pair Bchlorophylls and the bacteriopheophytins (Bpheophytins) $\sim 1500 \mathrm{~cm}^{-1}$ (147). $\left(\mathrm{P}_{\mathrm{A}} / \mathrm{P}_{\mathrm{B}}\right)^{*}$ in bacterial reaction centers decays in a multiexponential process to yield $\mathrm{P}^{+} \mathrm{Pheo}^{-}$with time constants ranging from 0.9 to $4 \mathrm{ps}$, which may involve $\mathrm{P}^{+} \mathrm{B}^{-}$ as an intermediate, but there is not unanimity of opinion in this regard [see Reference (147)]. In PSII, the reaction center chlorophylls are much more congested spectrally as their absorbance spectra heavily overlap. In contrast to the bacterial reaction centers, the overall absorption envelope of the PSII reaction centers is only approximately $500 \mathrm{~cm}^{-1}$ at half height. The excitonic coupling between the reaction center pigments is weak, with the homologous $\mathrm{P}_{\mathrm{A}}$ and $\mathrm{P}_{\mathrm{B}}$ chlorophylls suggested to show a coupling of approximately $85-140 \mathrm{~cm}^{-1}(11,118,134)$. The structural homology between the bacterial reaction centers and PSII and the similar time domains over which charge separation occurs would lead one to assume that primary charge separation in PSII occurs mechanistically as it does in the bacterial reaction center. The kinetics of primary charge separation in PSII, however, have been reported to show multiple phases for the formation of the $\mathrm{P}^{+} \mathrm{Pheo}^{-}$charge pair $(32,44,45,60,77)$. In addition, the triplet state of $\mathrm{P}$, formed by $\mathrm{P}^{+} \mathrm{Pheo}^{-}$ recombination at liquid helium temperature, has been shown in PSII $(131,135)$ to 
be localized on a monomeric chlorophyll with an orientation (ring plane $30^{\circ}$ with respect to the membrane plane) more like that of $\mathrm{B}_{\mathrm{A}}$ or $\mathrm{B}_{\mathrm{B}}$ rather than $\mathrm{P}_{\mathrm{A}}$ and $P_{B}$ as is seen in the bacterial reaction centers $(49,119)$. These observations have led a number of authors to suggest that primary charge separation might occur differently in PSII, potentially initiated by excitation of $\mathrm{B}_{\mathrm{A}}$ rather than $\mathrm{P}_{\mathrm{A}} / \mathrm{P}_{\mathrm{B}}$. A number of groups have shown in bacterial reaction centers that it is possible to observe, under certain conditions, the formation of radical pair states upon direct excitation of $\mathrm{B}_{\mathrm{A}}(69,128,130,142)$. Dekker \& van Grondelle (24) and Rutherford and coworkers $(98,99)$ have suggested that in PSII the lack of spectral differentiation and the orientation of ${ }^{3} \mathrm{P}$, respectively, might be consistent with a contribution of $\mathrm{B}_{\mathrm{A}}^{*}$ to primary radical formation. Key questions then are $(a)$ where is primary charge separation initiated and $(b)$ are the oxidized primary donor cation radical and the triplet localized on the same or on different chlorophylls, and if the latter, which one of the two has migrated and on what timescale?

\section{SPECTRA OF PSII REACTION CENTER CHLORINS}

\section{$\mathrm{P}_{\mathrm{A}}$, the Primary Site for $\mathrm{P}^{+}$Cation Localization}

Although it has been difficult to track the reaction center triplet and primary cation radical of PSII because of the spectral congestion mentioned above, there has been some success using Fourier transform infrared spectroscopy (FTIR). Noguchi et al. (80) and Breton and coworkers (101) have been able to show, based on the vibrational frequency of the $\mathrm{C}_{13} \mathrm{l}=\mathrm{O}\left(\mathrm{C}_{9}=\mathrm{O}\right)$ carbonyl, that the chlorophyll on which the reaction center triplet, ${ }^{3} \mathrm{P}$, is localized at low temperature $\left(1669 \mathrm{~cm}^{-1}\right)$ is different from the chlorophyll(s) on which the $\mathrm{P}^{+}$cation is localized $\left(1679\right.$ or $\left.1704 \mathrm{~cm}^{-1}\right)$.

More recently, Diner and coworkers (30) have introduced site-directed mutations that have permitted optical tagging of some of the reaction center chlorophylls. These tags have permitted the assignment of the Qy and Soret absorbance maxima to $\mathrm{P}_{\mathrm{A}}, \mathrm{P}_{\mathrm{B}}$, and $\mathrm{B}_{\mathrm{A}}$. Histidines D1-His198 and D2-His197 are the PSII homologues of histidines L-His173 and M-His200(202) of the bacterial reaction centers responsible for the coordination of chlorophylls $\mathrm{P}_{\mathrm{A}}$ and $\mathrm{P}_{\mathrm{B}}$, respectively. Both residues were replaced in PSII by a variety of amino acids that alter the reduction potentials of the coordinated chlorophylls and introduce displacements to the blue of their absorbance spectra. The latter is explained by the loss of the more polarizable His axial ligand, which stabilizes the chlorophyll excited state. Replacement of the $\mathrm{P}_{\mathrm{A}}$ ligand, D1-His198, with Gln resulted in the largest displacement $(3 \mathrm{~nm})$ to the blue of the $\mathrm{P}_{\mathrm{A}}$ absorbance spectrum for the Soret $(433 \rightarrow 430 \mathrm{~nm}$, $298 \mathrm{~K})$ and Qy transitions $(672.5 \rightarrow 669.5 \mathrm{~nm}, 80 \mathrm{~K})(30)$. That the $\mathrm{P}^{+}-\mathrm{P}$ difference spectrum at all temperatures shows this same shift argues that $\mathrm{P}_{\mathrm{A}}$ is the primary location of the $\mathrm{P}^{+}$cation independent of the temperature. Measurements of absorbance changes polarized parallel and perpendicular to the membrane plane indicate that the orientation of the Qy transition of the chlorophyll responsible for $\mathrm{P}^{+}\left(\mathrm{P}_{\mathrm{A}}^{+}\right)$is parallel to the membrane plane (71) (Figure 1). 
Most surprising among the site-directed replacements reported at D1-His198 and D2-His197 were those that did not introduce coordinating side chains (e.g., Ala, Val) (30). Introduction of Ala gave photoautotrophic strains in both cases. However, larger noncoordinating resides such as Leu (30) and Tyr (138) gave no reaction center. It is likely that in the case of the D1-His198Ala and the D2His197Ala mutations a water molecule has replaced the imidazole ring of histidine as the axial ligand to $\mathrm{Mg}^{2+}$. A residue like Leu would displace the water molecule preventing coordination, and deprotonation of the water ligand or $\mathrm{O}-\mathrm{H}$ bond stretch would explain the substantial stabilization $\left(\Delta \mathrm{E}^{\prime} \mathrm{P}^{+} / \mathrm{P} \sim-80 \mathrm{mV}\right)$ of $\mathrm{P}^{+}$by the Ala mutation relative to the wild-type strain. A similar replacement of the His coordination with a water molecule has been reported in the L-His173Gly and the M-His200Gly mutants of $R b$. sphaeroides $(43,105)$ and in the B-His656Glu mutant of PSI $(66,144)$. In contrast to PSII, however, replacement of each His ligand with Leu does allow assembly of the bacterial reaction center but with incorporation of a Bpheophytin in place of Bchlorophyll at the mutated site (14a, 58a). It is possible, in the case of PSII, that the binding energy contributed by the axial coordination is required for chlorin incorporation. In bacterial reaction centers, other residues must contribute sufficiently to allow Bchlorin binding.

The oxidation of redox active tyrosines, $\mathrm{Y}_{\mathrm{Z}}$ and $\mathrm{Y}_{\mathrm{D}}$, produces band shifts in the Soret and the Qy regions of the chlorophyll absorption spectra. For $\mathrm{Y}_{\mathrm{Z}}$, the band shift is sensitive to the D1-His198Gln mutation. The band shift is centered at $434 \mathrm{~nm}$ in wild type and at $432 \mathrm{~nm}$ in the mutant (30), indicating that $\mathrm{P}_{\mathrm{A}}$ is a major probe of the oxidation of this tyrosine. This observation and the $\mathrm{P}^{+}-\mathrm{P}$ difference spectrum indicate that the absorbance maxima for $\mathrm{P}_{\mathrm{A}}$ are located at 433 and $672.5 \mathrm{~nm}$ in wild type.

$\mathrm{P}_{\mathrm{B}}$

By symmetry, $\mathrm{P}_{\mathrm{B}}$ should be an analogous probe of the oxidation of $\mathrm{Y}_{\mathrm{D}}$. The Soret band shift for $\mathrm{Y}_{\mathrm{Z}^{-}}-\mathrm{Y}_{\mathrm{Z}}$ is centered at 433-434 nm (consistent with $\mathrm{P}_{\mathrm{A}}$ ), whereas for $Y_{D^{\bullet-}} Y_{D}$ it is centered at $436 \mathrm{~nm}$ (31). The Soret absorption maximum for $\mathrm{P}_{\mathrm{B}}$ is therefore located at $436 \mathrm{~nm}$. This 2-3-nm displacement of the absorbance maximum to the red for $\mathrm{P}_{\mathrm{B}}$ relative to $\mathrm{P}_{\mathrm{A}}$ is likely conserved in the Qy region, placing the probable absorbance maximum of $\mathrm{P}_{\mathrm{B}}$ at $675 \mathrm{~nm}$.

$\mathrm{B}_{\mathrm{A}}$

A band shift to the blue of electrochromic origin accompanies the formation of $\mathrm{P}^{+}$. This band is centered at $\sim 684 \mathrm{~nm}$ at $5 \mathrm{~K} \mathrm{(54)}$ and at $681-682 \mathrm{~nm}$ at $80 \mathrm{~K}$ (30). This same chlorophyll is also bleached upon formation of ${ }^{3} \mathrm{P}(684 \mathrm{~nm}$ at $5 \mathrm{~K}$, $682 \mathrm{~nm}$ at $80 \mathrm{~K}$ ) (see below for the mechanism of triplet formation) $(30,54)$. Both the $\mathrm{P}^{+}$-induced band shift and the ${ }^{3} \mathrm{P}-{ }^{1} \mathrm{P}$ difference spectrum are insensitive to the D1-His 198Gln site-directed mutation. This insensitivity, the observation of an electrochromic shift of an accessory Bchlorophyll to the blue upon formation of $\mathrm{P}^{+}$in bacterial reaction centers (147), the primary localization of $\mathrm{P}^{+}$on $\mathrm{P}_{\mathrm{A}}$, and the 
reaction center triplet orientation all support the assignment of the 681-682-nm $(684 \mathrm{~nm}$ at $5 \mathrm{~K})$ feature to the Qy transition of $\mathrm{B}_{\mathrm{A}}$.

\section{$\mathrm{Pheo}_{\mathrm{A}}$ and $\mathrm{Pheo}_{\mathrm{B}}$}

Borohydride reduction of the inactive branch pheophytin, $\mathrm{Pheo}_{\mathrm{B}}$ (109) and exchange of $\mathrm{Pheo}_{\mathrm{B}}(39,40,108)$ and partial exchange of $\mathrm{Pheo}_{\mathrm{A}}(40,39)$ with $13^{1}$-deoxo- $13^{1}$-hydroxy-pheophytin $a$ indicate clearly that both pheophytins have their Qy absorption maxima at 676-680 nm (at $6 \mathrm{~K}$ ). Linear dichroism indicates that the Qy transitions are perpendicular to the membrane plane (39) (Figure 1). The Qx transitions of both pheophytins are located at $543 \mathrm{~nm}$ (at $6 \mathrm{~K}$ ) (40). In bacterial reaction centers, the $Q x$ transition is sensitive to hydrogen bonding to the $\mathrm{C}_{13^{1}}=\mathrm{O}$ of the exocyclic ring $(15,18)$. Moënne-Loccoz et al. (76) have shown using Resonance Raman spectroscopy that $\mathrm{Pheo}_{\mathrm{A}}$ in PSII is likely hydrogen bonded (as it is in bacterial reaction centers), with residue D1-130 being the likely homologue of the bacterial L-104. Indeed, Giorgi et al. (42) have shown that Synechocystis sitedirected mutations D1-Gln130Glu and D1-Gln130Leu displace the Qx band to longer and shorter wavelength, respectively, consistent with a strengthening and a disappearance of the $\mathrm{C}_{13} \mathrm{l}=\mathrm{O}$ hydrogen bond. This finding was recently confirmed by a high-field electron paramagnetic resonance (EPR) spectroscopy study of PSII core complexes bearing mutations at this position (33). That the Qx transitions of both PSII pheophytins are located at $543 \mathrm{~nm}$ implies that they are bound with hydrogen bonds of equal strength. Resonance Raman spectra of PSII core complexes in which each of the pheophytins is replaced by a chlorophyll (D. Force, A. Pascal, B. Robert \& B. Diner, in preparation) show, in each case, the loss of a similar feature at $1685 \mathrm{~cm}^{-1}$ arising from a hydrogen-bonded carbonyl group (A. Pascal, personal communication). This observation also indicates directly that both pheophytins have similar hydrogen-bond strengths to the $\mathrm{C}_{13^{1}}=\mathrm{O}$ carbonyl. It had been proposed earlier that one possible distinction between the active and inactive branches of the reaction center might be the presence of a hydrogen-bonded pheophytin on the active branch and the absence of a hydrogen bond on the inactive branch (76). The above observations rule out this hypothesis.

$\mathrm{B}_{\mathrm{B}}$

Replacement of the inactive branch Pheo $_{\mathrm{B}}$ with $13^{1}$-deoxo- $13^{1}$-hydroxy-pheophytin $a$ results in the loss of the Pheo Qy transition at 676-680 nm but also causes the blue shift of a transition at $680 \mathrm{~nm}$ that is attributed to $B_{B}(39)$. Replacement of Pheo $_{A}$ induces a blue-shifted transition at approximately $682 \mathrm{~nm}$ that is attributed to $\mathrm{B}_{\mathrm{A}}$, in agreement with the above assignment.

\section{$\mathrm{Chl}_{\mathrm{ZD} 1}$ and $\mathrm{Chl}_{\mathrm{ZD} 2}$}

A linear dichroism study (39) and characterization of a PSII reaction center complex containing five chlorophylls (126) both attribute to $\mathrm{Chl}_{\mathrm{ZD} 1}$ and to $\mathrm{Chl}_{\mathrm{ZD} 2}$ a 670-nm Qy transition oriented nearly perpendicular to the membrane plane 
(Figure 1). The assignments of the absorption maxima of the reaction center chlorins are summarized in Figure 1.

\section{REACTION CENTER TRIPLET, ${ }^{3} \mathrm{P}$}

The energetic consequences of the spectral assignments described above provide new insights into the mechanism of charge separation and the localization of the reaction center triplet state, ${ }^{3} \mathrm{P}$. Under conditions where $\mathrm{P}^{+} \mathrm{Pheo}^{-}$cannot relax to form $\mathrm{P}^{+} \mathrm{Q}_{\mathrm{A}}^{-}$either because $\mathrm{Q}_{\mathrm{A}}$ is reduced or absent, there is a decorrelation of the spins on the radical pair resulting in singlet/triplet mixing. Recombination of the triplet state of the radical pair gives rise to a reaction center triplet state that forms with a $\tau \sim 30 \mathrm{~ns}$ at room temperature (20) and slows as a function of temperature $(81,141)$ to $100-200 \mathrm{~ns}$ at $10 \mathrm{~K}(58,134)$. The energy of the ${ }^{3} \mathrm{P}$ is estimated to be $0.54 \mathrm{eV}$ below the singlet state (141). The triplet resides on a monomeric chlorophyll $(25,34,100,114,134)$ and has the gz component of its anisotropic g-tensor oriented at $60^{\circ}$ with respect to the membrane plane $(68,135)$; both findings are consistent with ${ }^{3} \mathrm{P}$ residing on $\mathrm{B}_{\mathrm{A}}$ or $\mathrm{B}_{\mathrm{B}}$. This localization is in contrast to what is found in the bacterial reaction centers where the triplet resides on one or both $\mathrm{P}_{\mathrm{A}}$ and $\mathrm{P}_{\mathrm{B}}(49,119)$. The comparison of the optical difference spectrum ${ }^{3} \mathrm{P}_{-}{ }^{1} \mathrm{P}$ with that of $\mathrm{P}^{+}-\mathrm{P}$ (see above) indicates that the triplet is localized on a chlorophyll absorbing at $684 \mathrm{~nm}$ at $5 \mathrm{~K}(30,54,55)$. This chlorophyll was associated with the electrochromic band shift observed upon formation of $\mathrm{P}_{\mathrm{A}}^{+}$and so is attributed primarily to $\mathrm{B}_{\mathrm{A}}$ rather than to $\mathrm{B}_{\mathrm{B}}$ in PSII (30).

Assuming very weak coupling of the singlet states of the reaction center chlorophylls, the energy of the triplet state should track that of the singlet state (72). As $\mathrm{B}_{\mathrm{A}}$ is the longest wavelength chlorophyll of the reaction center, it is now understandable why the triplet is localized on $\mathrm{B}_{\mathrm{A}}$ at $5 \mathrm{~K}$ rather than on $\mathrm{P}_{\mathrm{A}}$, the major site of cation localization at all temperatures. It is not clear whether the triplet is actually generated at $\mathrm{P}_{\mathrm{A}}$ or $\mathrm{Pheo}_{\mathrm{A}}$ by recombination of $\mathrm{P}_{\mathrm{A}}^{+} \mathrm{Pheo}_{\mathrm{A}}^{-}\left(\right.$or $\mathrm{P}_{\mathrm{A}}^{+} \mathrm{B}_{\mathrm{A}}^{-}$or $\mathrm{B}_{\mathrm{A}}^{+} \mathrm{Pheo}_{\mathrm{A}}^{-}$), migrating to $\mathrm{B}_{\mathrm{A}}$ at a rate faster than triplet formation, or whether it is the cation that migrates to $\mathrm{B}_{\mathrm{A}}$ or the anion that migrates to $\mathrm{B}_{\mathrm{A}}$ from $\mathrm{P}_{\mathrm{A}}^{+} \mathrm{Pheo}^{-}$. At this point, the triplet would be formed, respectively, by $\mathrm{B}_{\mathrm{A}}^{+} \mathrm{Pheo}_{\mathrm{A}}^{-}$or $\mathrm{P}_{\mathrm{A}}^{+} \mathrm{B}_{\mathrm{A}}^{-}$ recombination, thus directly forming the triplet on $\mathrm{B}_{\mathrm{A}}$.

Although the triplet is clearly localized on $\mathrm{B}_{\mathrm{A}}$ at $\leq 80 \mathrm{~K}$, the localization of ${ }^{3} \mathrm{P}$ changes as the temperature rises $(10,58,78,80)$. At elevated temperature $(\geq 150 \mathrm{~K})$, another chlorophyll(s) begins to contribute to the reaction center triplet population. This chlorophyll has a $\mathrm{C}_{13} \mathrm{l}=\mathrm{O}$ stretch like that of $\mathrm{P}_{\mathrm{A}}(80,101)$ and is oriented perpendicular to the membrane plane (58). Over the same temperature range, the ${ }^{3} \mathrm{P}-{ }^{1} \mathrm{P}$ difference spectrum begins to show a short wavelength shoulder, the position of which is sensitive to the D1-His198Gln mutation (30). All of these observations are consistent with an increased sharing of the reaction center triplet with $\mathrm{P}_{\mathrm{A}}$ at elevated temperature. The temperature dependence of the triplet localization is consistent with an energy gap $\Delta \mathrm{E}$ of $8-13 \mathrm{meV}$ that would correspond to the difference in the triplet state energies of $\mathrm{B}_{\mathrm{A}}$ and $\mathrm{P}_{\mathrm{A}}(10,58,78,80)$. 


\section{SHARING OF THE CATION RADICAL}

Diner et al. (30) have proposed that the $\mathrm{P}^{+}$cation radical is primarily localized on $\mathrm{P}_{\mathrm{A}}^{+}$. A mid-IR band at $1940 \mathrm{~cm}^{-1}$ detected by FTIR (80; J. Breton, personal communication) and methyl hyperfine couplings measured by electron nuclear double resonance (ENDOR) $(93,117)$ both gave indications of some delocalization of the $\mathrm{P}^{+}$cation. The ENDOR measurements were consistent with an approximate 80:20 distribution between two or more chlorophylls with one chlorophyll dominating (now known to be $\mathrm{P}_{\mathrm{A}}^{+}$). The D2-His197Ala mutation gave $\sim 1$-nm displacement of the $\mathrm{P}^{+}-\mathrm{P}$ difference spectrum to the red, whereas the same mutation on D1-His198Ala produced a 2-nm shift to the blue (30). This observation is consistent with a displacement of the $\mathrm{P}^{+}$cation toward $\mathrm{P}_{\mathrm{B}}$ in the D2-His197Ala mutant through stabilization of $\mathrm{P}_{\mathrm{B}}^{+}$. This ability to control the position of the cation suggests the possibility that its position might be subject to electrostatic control as well (see below).

\section{PRIMARY CHARGE SEPARATION}

It would appear from the spectral assignments discussed above that $\mathrm{B}_{\mathrm{A}}$ is the longest wavelength chlorin located within the reaction center. Additional support for this conclusion comes from a study by Konermann \& Holzwarth (63) of the spectral decomposition of the PSII reaction center at $10 \mathrm{~K}$, which led these authors to conclude that $\mathrm{B}_{\mathrm{A}}$ or $\mathrm{B}_{\mathrm{B}}$ was responsible for the longest wavelength emission. Furthermore, Peterman et al. (85) have measured at $5 \mathrm{~K}$ the vibronic fine structure of a line-narrowed emission spectrum upon excitation of PSII reaction centers at $684-686.1 \mathrm{~nm}$. The emission spectrum, which should arise from the longest wavelength-emitting component of the reaction center, shows a $\mathrm{C}_{13}=\mathrm{O}\left(\mathrm{C}_{9}=\mathrm{O}\right)$ carbonyl stretch at $1669 \mathrm{~cm}^{-1}$. Such a feature has been assigned by Noguchi and coworkers to $\mathrm{B}_{\mathrm{A}}(80,81)$.

At $5 \mathrm{~K}$, the ratio of finding the excitation energy on $\mathrm{B}_{\mathrm{A}}(684 \mathrm{~nm})$ versus $\mathrm{P}_{\mathrm{A}}$ $(672.5 \mathrm{~nm}) \mathrm{B}_{\mathrm{A}}^{*} / \mathrm{P}_{\mathrm{A}}^{*}$ (Figure 4 ) is approximately $10^{31}$, based on Boltzmann considerations (singlet state energy difference of $31 \mathrm{meV}$ ). This partition, for Synechocystis, is somewhat more extreme than for spinach and Synechococcus $\left(10^{21}-10^{24}\right)$ where

Figure 4 The relative localization of the excitation energy on the central components of the PSII reaction center at 5, 77, and $298 \mathrm{~K}$. The shaded area corresponds to the percent of the total excitation on that component, calculated from the Boltzmann equation using the absorbance maxima of Figure 1. This distribution is calculated at each temperature based on the absorbance maxima of the chromophores at $5 \mathrm{~K}$. The use of the $5-\mathrm{K}$ spectrum is certainly an over simplification at $298 \mathrm{~K}$, but the energy is broadly distributed anyway at the latter temperature. 

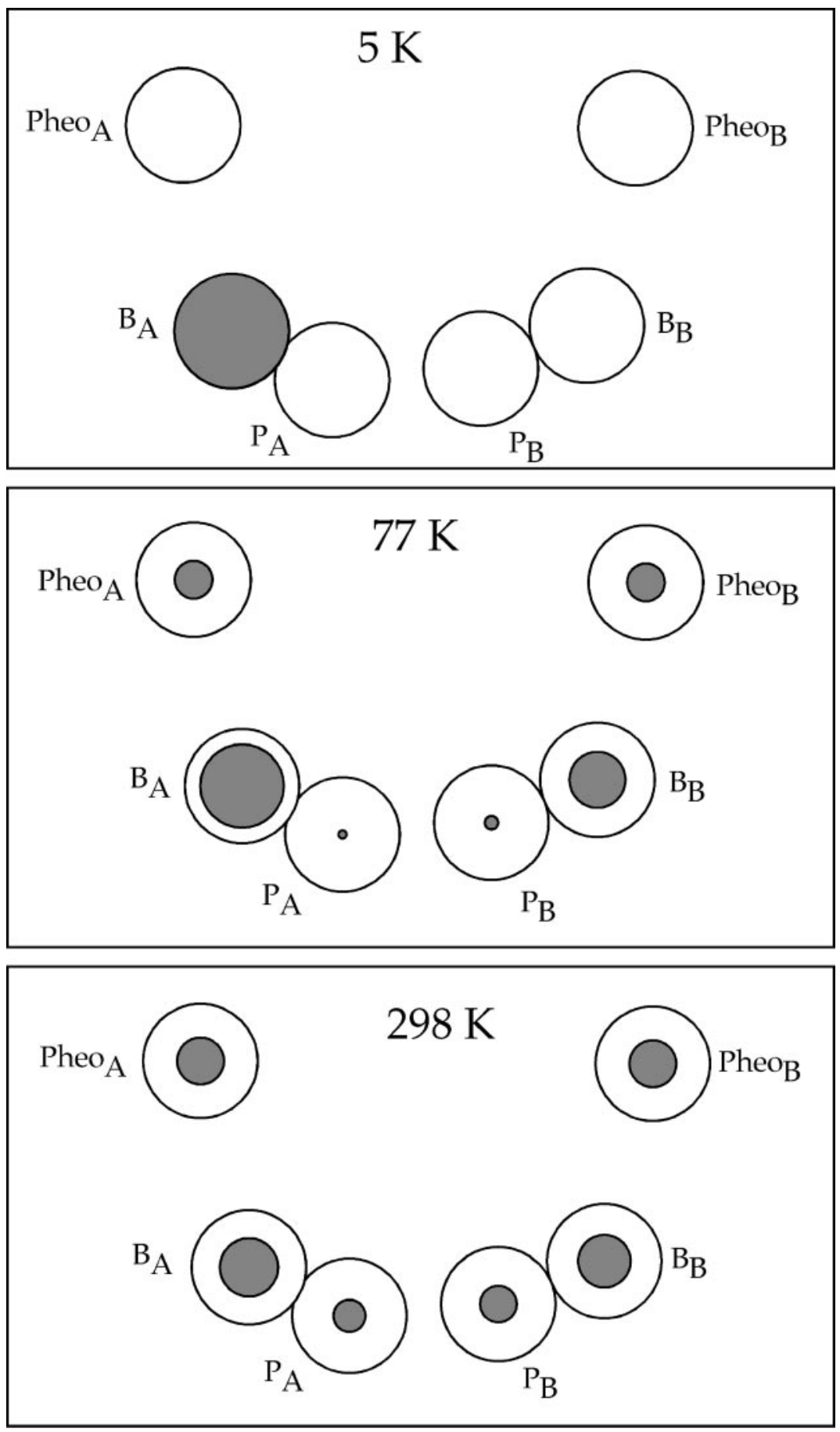
the absorbance maxima of $\mathrm{P}_{\mathrm{A}}$ are likely located at $676 \mathrm{~nm}$ and $675 \mathrm{~nm}$, respectively $(54,55)$. For $\mathrm{B}_{\mathrm{A}}$ and $\mathrm{Pheo}_{\mathrm{A}}(680 \mathrm{~nm})$, the $\mathrm{B}_{\mathrm{A}}^{*} / \mathrm{Pheo}_{\mathrm{A}}^{*}$ ratio at $5 \mathrm{~K}$ is $5.6 \times 10^{10}$. As the rate of charge separation is generally thought to be slower than that of energy equilibration [but see (47)] between the reaction center pigments (100-250 fs) $(35,77)$, the excited state responsible for charge separation will be exclusively localized on $\mathrm{B}_{\mathrm{A}}$ at this temperature. That charge separation can occur at $\leq 20 \mathrm{~K}$ on the ps timescale with high quantum yield $(\sim 75 \%)(47,57,143)$ implies that it must be occurring from $\mathrm{B}_{\mathrm{A}}^{*}$. The two likely radical pair products are $\mathrm{P}_{\mathrm{A}}^{+} \mathrm{B}_{\mathrm{A}}^{-}$and $\mathrm{B}_{\mathrm{A}}^{+} \mathrm{Pheo}_{\mathrm{A}}^{-}$(Figure 5). van Broderode et al. (129) have shown that direct excitation of $\mathrm{B}_{\mathrm{A}}$ will produce $\mathrm{P}_{\mathrm{A}}^{+} \mathrm{B}_{\mathrm{A}}^{-}$as the initial radical pair in $R b$. sphaeroides reaction centers. These authors have also shown that excitation of $\mathrm{B}_{\mathrm{A}}$ in reaction centers in which the special pair Bchlorophylls have been replaced by a Bchlorophyll:Bpheophytin heterodimer (M-His202Leu mutant) will produce predominantly $\mathrm{B}_{\mathrm{A}}^{+} \mathrm{Pheo}^{-}$as the initial radical pair (130).

The observations in PSII at low temperature of a long-lived singlet excited state arising from a chlorophyll absorbing at $683 \mathrm{~nm}(63,64)$ with spectral similarities to the charge-separating state (85) would imply that the radical pair state(s) generated from $\mathrm{B}_{\mathrm{A}}^{*}$ is(are) nearly equipotential with $\mathrm{B}_{\mathrm{A}}^{*}$. Were there a distribution of the energies of these states, then some fraction of them would require thermal activation and at $5 \mathrm{~K}$ might be inaccessible, giving rise to long-lived fluorescence $(24,85)$. Indeed, Groot et al. (47) have shown that charge separation in PSII reaction centers is to some extent an activated process.

Konermann et al. (64) and Peterman et al. (85) were unable to detect fluorescence emission from Pheo* at 5-10 K. However, at $77 \mathrm{~K}$, Pheo* is apparent with a ratio of $\mathrm{Chl}^{*} / \mathrm{Pheo}^{*}$ of 4:1 (64) (Figure 4). This observation is consistent with a 4$\mathrm{nm}(10.5 \mathrm{meV})$ difference between the energies of the lowest excited singlet states of $\mathrm{B}_{\mathrm{A}}(684 \mathrm{~nm})$ and Pheo $(680 \mathrm{~nm})$. It is possible then that Pheo* could begin to contribute to radical pair formation as the temperature increases, generating $\mathrm{B}_{\mathrm{A}}^{+} \mathrm{Pheo}^{-}$ as the initial product. At $298 \mathrm{~K}$, the energy is likely to be distributed over all of the central pigments of the reaction center with $\mathrm{B}_{\mathrm{A}}^{*}$ representing no more than $25 \%$ of the total (Figures 4 and 5). All of the active branch pigments could contribute to radical pair formation, although the relative contributions to charge separation from the different excited states are likely to be different depending on their rates of charge separation and on the relative energies of the radical pair and excited states. The observed heterogenity in charge separation in reaction centers is then likely to arise from the heterogeneity of excited states that contribute to it, the inhomogeneous broadening of the optical transitions (48), a distribution of energy levels for a single radical pair state $(48,62)$, a succession of increasingly stabilized radical pair states accessed through electron transfer $(24,62)$, and relaxations within the protein matrix (Dynamic Solvation Model) $(24,62,84)$. Proposals by Dekker \& van Grondelle (24) situate primary radical pair formation in $\leq 2 \mathrm{ps}$, expanded radical pair formation in $\sim 8 \mathrm{ps}$, and protein relaxation on the $50 \mathrm{ps}$ time scale. Where excited, the $\mathrm{Chl}_{\mathrm{ZD} 1}$ and $\mathrm{Chl}_{\mathrm{ZD} 2}$ would contribute 20-30 ps components that are limited by energy transfer to the central pigments of the reaction center. 


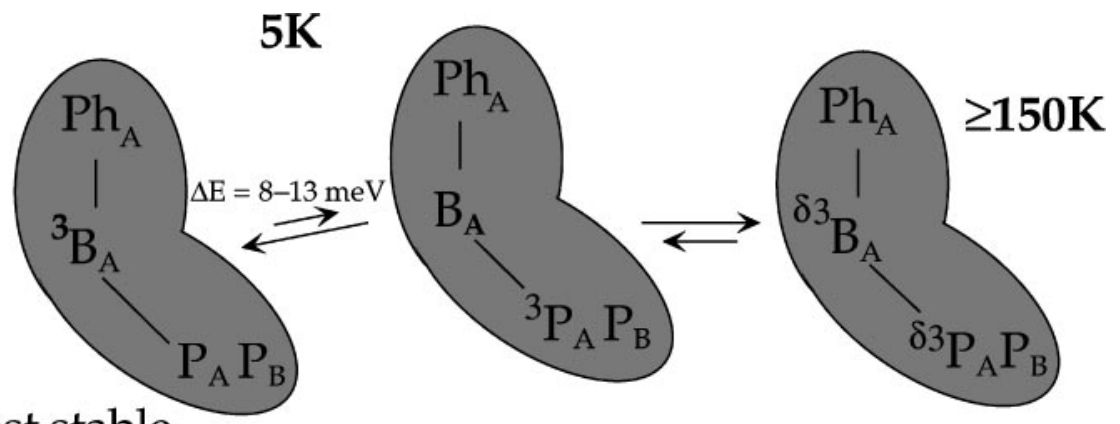

\section{Most stable triplet state}

$\mathrm{Q}_{\mathrm{A}}$ reduced

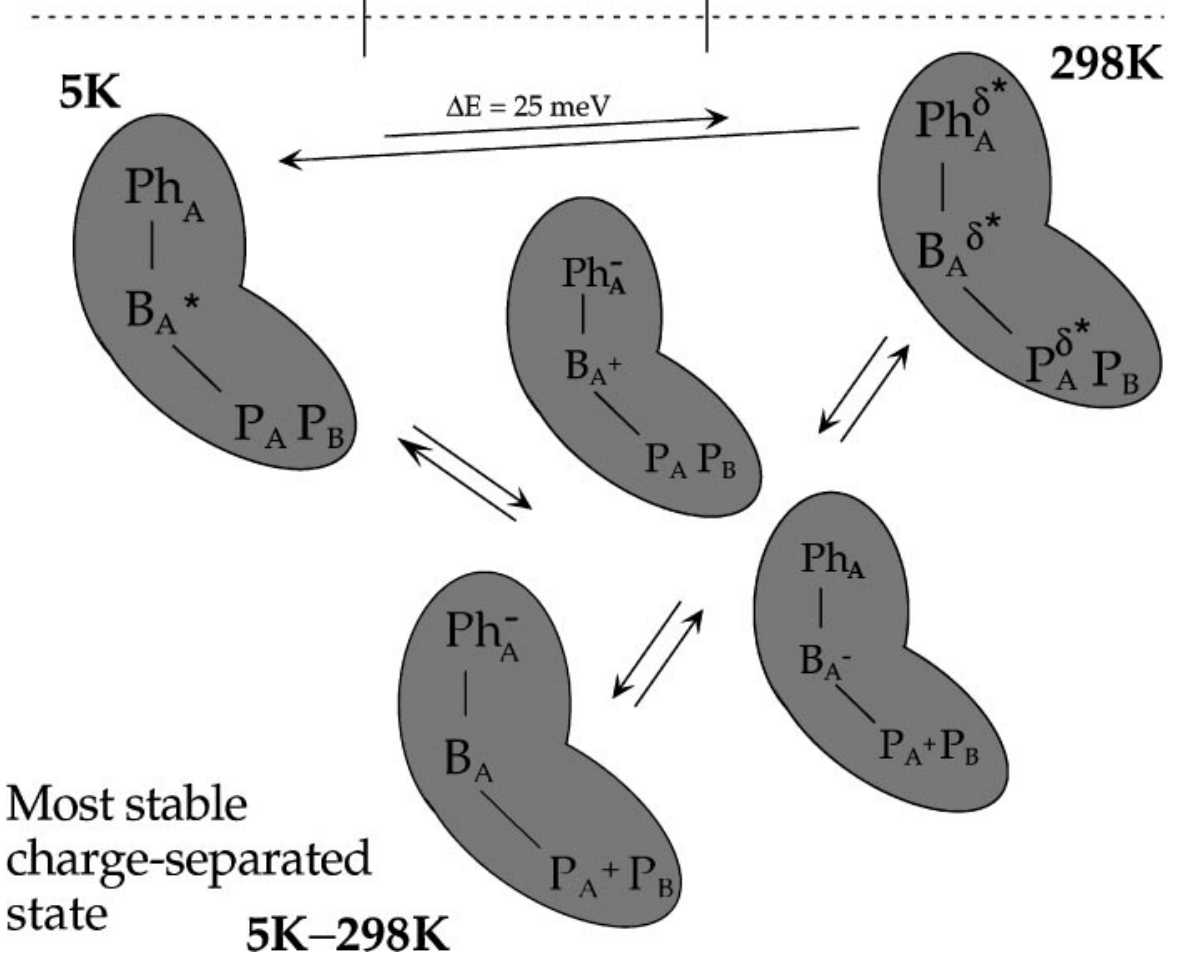

Figure 5 The localization as a function of temperature of the singlet excited states before charge separation and of the triplet and radical pair states after charge separation, in the active branch of the PSII reaction centers. 
A number of groups have directly measured the depth of the PSII trap. In plants, the free-energy gap between the equilibrated singlet excited state and $\mathrm{P}^{+} \mathrm{Pheo}^{-}$, measured at $60 \mathrm{ps}$ following actinic excitation at $298 \mathrm{~K}$, is only $-27 \mathrm{meV}$ (74), increasing to -46 to $\sim-110 \mathrm{meV}$ on the nanosecond timescale $(8,48,62,141)$, consistent with the Dynamic Solvation Model mentioned above. Site-directed mutations constructed in Synechocystis 6803 that increase the reduction potential of $\mathrm{P}^{+} / \mathrm{P}$ (D1-His198Gln, $\Delta \mathrm{G} \sim 16 \mathrm{meV}$ ) or lower the reduction potential of $\mathrm{Pheo} / \mathrm{Pheo}^{-}$by removing a hydrogen bond to the $\mathrm{C}_{13^{1}}=\mathrm{O}$ carbonyl (D1-Gln130Leu, $\Delta \mathrm{G} \sim 53 \mathrm{meV}$ ) produce significant decreases in the concentration of the radical pair detected at $60 \mathrm{ps}$. In Synechocystis, the D1-Gln130 hydrogen bond to $\mathrm{C}_{13^{1}}=\mathrm{O}$ raises by $\sim 36 \mathrm{meV}$ the energy of the $\mathrm{P}^{+} \mathrm{Pheo}^{-}$state relative to the same state where D1-130 is a Glu as in higher plants (74). Thus in wild-type Synechocystis, $\mathrm{P}^{+} \mathrm{Pheo}^{-}$ is actually $\sim 21 \mathrm{meV}$ above the excited state energy at $60 \mathrm{ps}$. A consequence of this uphill process for radical pair formation is that the electron transfer from $\mathrm{Pheo}^{-}$ to $\mathrm{Q}_{\mathrm{A}}(250-300 \mathrm{ps})$ should appear as a component in the excited state relaxation.

\section{DONOR-SIDE SECONDARY ELECTRON TRANSFER}

The redox active tyrosines, $\mathrm{Y}_{\mathrm{Z}}$ and $\mathrm{Y}_{\mathrm{D}}$ (D1-Tyr161 and D2-Tyr160, respectively) [for reviews see $(23,26,27)$ ], act as secondary electron donors and are oxidized to form the neutral radicals, releasing the phenolic proton. Site-directed mutagenesis has implicated D1-His190 and D2-His189 as the immediate proton acceptors for $\mathrm{Y}_{\mathrm{Z}}$ and $\mathrm{Y}_{\mathrm{D}}$, respectively [see $(23,26)$ and references therein]. Pulsed ENDOR measurements have indicated direct hydrogen bonding of the proton on the $\tau$-imidazole nitrogen of D2-His 189 to $\mathrm{Y}_{\mathrm{D}^{\bullet}}$ (16). FTIR measurements indicate that this same His is hydrogen bonded by the phenolic proton of $Y_{D}(53)$. However, there is no clear evidence to indicate the formation of the imidazolium form of histidine $(53,82)$ upon tyrosine oxidation, implying that the proton on the $\pi$-imidazole nitrogen of D2-His189 is likely transferred to a proton acceptor. The proton may, however, remain associated with the acceptor and back hydrogen bond. If the hydrogenbonded chain were to extend to the bulk phase, then it is possible that the positive charge of the proton could be dissipated by proton release at the surface. In the case of $Y_{Z}$, the situation is even less clear. Site-directed replacement of D1-His190 causes a substantial slowing of $\mathrm{Y}_{\mathrm{Z}}$ oxidation $(29,52)$, consistent with a similar role as the acceptor of the phenolic proton of $\mathrm{Y}_{\mathrm{Z}}$. However, pulsed ENDOR measurements do not indicate a direct hydrogen bond between the two, as in the case of $Y_{D}$ (K. Campbell \& R. David Britt, personal communication). Either the two are indirectly linked by intermediary waters or amino acid residue side chains or the hydrogen-bonded interaction between the two is intermittent (gated). Thus for both tyrosines, either the released proton is distributed among a number of likely hydrogen-bonded residues or the charge, if not the actual proton, is released to the bulk phase. There has been considerable debate over this issue, as it has repercussions for the hydrogen atom abstraction model for water oxidation that implicates $\mathrm{Y}_{\mathrm{Z}}$ directly in this mechanism $(13,120)$. This model is a consequence of recent 
demonstrations of the close proximity between $Y_{Z}$ and the Mn cluster $(113,116)$, the lowered activation energy that results from having a strong base prepositioned to accept a proton from bound water as the Mn cluster is being oxidized $(67,145)$, and the difference in bond dissociation energies that favor hydrogen atom transfer from the Mn cluster to $Y_{Z^{\bullet}}(6,83)$. In this model, the phenolic proton of $Y_{Z}$ has been proposed to be released to the lumen upon $Y_{Z}$ oxidation. The proton-coupled reduction of $\mathrm{Y}_{Z^{*}}$ with the proton coming from a water molecule ligated to the $\mathrm{Mn}$ cluster would then decrease the energetic levels of the reaction intermediates and increase the driving force for the catalysis for water oxidation.

\section{RETENTION OF TYROSINE PHENOLIC PROTON AND ELECTROSTATICS}

A number of authors have argued, however, that the $\mathrm{Y}_{\mathrm{Z}}$ phenolic proton is retained within the reaction center following oxidation $(1,30,31,86,87)$, giving rise to a chlorophyll band shift of electrochromic origin in the Soret and Qy spectral regions. A similar band shift is observed accompanying the oxidation of $Y_{D}$ but shifted by 2-3 nm to the red (31) (see above). The very slow exchange of the phenolic $Y_{D}$ proton upon replacement of $\mathrm{H}_{2} \mathrm{O}$ with $\mathrm{D}_{2} \mathrm{O}\left[\mathrm{t}_{1 / 2} \sim 9 \mathrm{~h}(28,94)\right]$ also argues for proton retention upon oxidation of this tyrosine. If instead the phenolic proton were released to the thylakoid lumenal space, then there would be no retained charge, and another explanation would need to be sought to explain the band shift [e.g., a structural change or a hydrogen-bond displacement (122)]. Arguments for proton retention include a $\mathrm{pH}$ dependence for proton release coupled to $\mathrm{Y}_{\mathrm{Z}}$ oxidation that turns off below $\mathrm{pH} 5$ even though the $\mathrm{pK}_{\mathrm{a}}$ of the tyrosyl cation radical is approximately -2 (87). In addition, Rappaport \& Lavergne (86) have observed an oscillation of period four of a very similar band shift in the Soret that appears upon S-state advances that do not give rise to proton release (e.g., S1 $\rightarrow$ S2, generation of a plus charge).

The ability to shift the position of the $\mathrm{P}^{+}$cation between $\mathrm{P}_{\mathrm{A}}$ and $\mathrm{P}_{\mathrm{B}}$ by ligand replacement and the difference in the absorbance maxima of $\mathrm{P}_{\mathrm{A}}$ and $\mathrm{P}_{\mathrm{B}}(30)$ mean that the $\mathrm{P}^{+}-\mathrm{P}$ difference spectrum can be used as an electrostatic indicator of nearby charges. Boerner et al. (7) reported and Diner and coworkers (unpublished) later confirmed that the rate of charge recombination between $\mathrm{P}^{+}$and $\mathrm{Q}_{\mathrm{A}}^{-}$is influenced by the presence of $Y_{D^{*}}$. D2-Tyr160Phe, a mutant lacking $Y_{D}$, showed a rate of charge recombination nearly twice that observed in wild type. This observation is consistent with the positive charge generation associated with $\mathrm{Y}_{\mathrm{D}^{*}}$, which in wild type would increase the reduction potential of $\mathrm{P}^{+} / \mathrm{P}$, thereby decreasing both the concentration of $\mathrm{P}^{+}$at the expense of $\mathrm{Y}_{\mathrm{Z}}$ and the rate of charge recombination between $\mathrm{P}^{+}$and $\mathrm{Q}_{\mathrm{A}}^{-}\left(\mathrm{Y}_{\mathrm{Z}^{*}}\right.$ and $\mathrm{Q}_{\mathrm{A}}^{-}$are too far apart to allow a competitive direct electron transfer). The positive charge would likely also influence the position of the $\mathrm{P}^{+}$cation between $\mathrm{P}_{\mathrm{A}}$ and $\mathrm{P}_{\mathrm{B}}$. If we place D2-His190 at roughly 13 and $20 \AA$, respectively, from $\mathrm{P}_{\mathrm{B}}$ and $\mathrm{P}_{\mathrm{A}}$ and assume that most of the positive charge is in the immediate environment of the histidine upon $Y_{D}$ oxidation, then one can do a rough 
electrostatic calculation on the potential opposing the movement of a plus charge from $\mathrm{P}_{\mathrm{A}}^{+}$to $\mathrm{P}_{\mathrm{B}}$. This calculation gives a potential difference of 147 and $59 \mathrm{mV}$ for a dielectric constant of 4 and 10 , respectively, which is larger than the estimated $40 \mathrm{mV}$ difference in reduction potential of $\mathrm{P}_{\mathrm{A}}^{+} / \mathrm{P}_{\mathrm{A}}$ and $\mathrm{P}_{\mathrm{A}}^{+} / \mathrm{P}_{\mathrm{B}}$ (30). The charge that accompanies $Y_{D}$ oxidation would therefore be expected to have a substantial influence on the localization of the $\mathrm{P}^{+}$cation. Indeed, Faller et al. (37) have recently suggested that the $\mathrm{P}^{+}$reduction rate by $\mathrm{Y}_{\mathrm{Z}}$ is slower in the presence of $\mathrm{Y}_{\mathrm{D}}$ than $Y_{D^{*}}$. It was proposed that, owing to electrostatic interaction, the propensity of the cation to reside on $\mathrm{P}_{\mathrm{A}}$ (the closest $\mathrm{Chl}$ to $\mathrm{Y}_{\mathrm{Z}}$ ) would be larger in the presence of $\mathrm{Y}_{\mathrm{D}}$. J. Bautista \& B. Diner (unpublished) have examined the $\mathrm{P}^{+}-\mathrm{P}$ difference spectrum in the presence and absence of $Y_{D}$ and have found that, indeed, the mutant lacking $Y_{D}$ shows a difference spectrum shifted by approximately $0.5 \mathrm{~nm}$ to the red relative to that of the wild type. This finding is consistent with the probability that the cation residing on $\mathrm{P}_{\mathrm{B}}$ is larger in the absence of $\mathrm{Y}_{\mathrm{D}^{*}}$. These observations are consistent with charge retention and the electrochromic interpretation of the very similar $Y_{Z^{*}}-Y_{Z}$ and the $Y_{D^{--}} Y_{D}$ band shifts. In addition, Ananyev et al. (2) have found that the loss of $Y_{D}$ greatly slows the photoactivated assembly of the Mn cluster relative to wild type. This observation has also been interpreted in terms of an enhancement by $\mathrm{Y}_{\mathrm{D}}$ of the $\mathrm{P}^{+} / \mathrm{P}$ reduction potential, thereby increasing the driving force for $\mathrm{Mn}$ oxidation. These observations provide a rationale for the evolutionary retention of $Y_{D}$ even though it is on a side path to the main electron transport pathway that leads to water oxidation.

\section{ALTERNATE ELECTRON DONORS}

Illumination under conditions in which the normal donor side electron transfer reactions $\left(\mathrm{Y}_{\mathrm{Z}} / \mathrm{Mn}\right.$ oxidation) are blocked (e.g., low temperature) results in the oxidation of alternate electron donors. These include the formation of a $\beta$-carotene cation radical [Car $\left.{ }^{+}, \varepsilon_{990 \mathrm{~nm}}=160 \mathrm{mM}^{-1} \mathrm{~cm}^{-1}(115)\right][(79,104)$; for review see (124)], a chlorophyll cation radical $\left[\mathrm{Chl}_{\mathrm{Z}}^{+}, \varepsilon_{820 \mathrm{~nm}}=7.0 \mathrm{mM}^{-1} \mathrm{~cm}^{-1}\right.$ (9)] (140), and an oxidized cytochrome $b_{559}$ [cyt $b_{559}, \varepsilon_{560-570 \mathrm{~nm}}=17.5 \mathrm{mM}^{-1} \mathrm{~cm}^{-1}$ (19)] [for review see $(19,110)$ ]. The $\mathrm{Chl}_{\mathrm{Z}}^{+}$has been attributed to one of the two chlorophylls coordinated by D1-His1 18 and D2-His 117 ( $\mathrm{Chl}_{\mathrm{ZD} 1}$ and $\mathrm{Chl}_{\mathrm{ZD} 2}$, respectively) (Figure 1). This designation is based on several factors: $(a)$ the location of these histidines in the second transmembrane helix of D1 and D2 (75), (b) the kinetics of energy transfer from peripheral chlorophylls to the central pigments in PSII reaction centers $(103),(c)$ the distance $(39.5 \pm 2.5 \mathrm{~nm})$ of $\mathrm{Chl}_{\mathrm{Z}}^{+}$from the PSII nonheme iron, measured using saturation-recovery EPR (65), and $(d)$ the perturbation of the $\mathrm{Chl}_{\mathrm{Z}}^{+}$Resonance Raman spectrum by site-directed mutations at D1-His118 in Synechocystis 6803 (111).

When cyt $b_{559}$ is reduced, it is the only cytochrome that is stabily oxidized at temperatures $\leq 100 \mathrm{~K}$. If the cytochrome is oxidized prior to illumination, then $\mathrm{Chl}_{\mathrm{Z}}^{+}$and Car are photooxidized, with the relative proportions of the two dependent on the temperature and on the nature of the PSII preparation. In addition, there 
appear to be two components to $\mathrm{Chl}_{\mathrm{Z}}^{+}$absorbing at $814 \mathrm{~nm}$ (in Synechocystis 6803; $817 \mathrm{~nm}$ in spinach) and at $850 \mathrm{~nm}$ (only observed in spinach) (123). Tracewell et al. (123) have suggested that these signals arise from $\mathrm{Chl}_{\mathrm{ZD} 1}^{+}$and $\mathrm{Chl}_{\mathrm{ZD} 2}^{+}$, respectively. The oxidation of these chlorophylls is accompanied by very strong signals arising from $\mathrm{Car}^{+}$at $987 \mathrm{~nm}$ (Synechocystis) and $994 \mathrm{~nm}$ (spinach) and by a vibronic band at $878 \mathrm{~nm}$ and $895 \mathrm{~nm}$, respectively. As the temperature is raised from $20 \mathrm{~K}$ to $120 \mathrm{~K}$, the component at $850 \mathrm{~nm}$ increases at the expense of the $\mathrm{Car}^{+}$signal (123). Additionally, if $\mathrm{Car}^{+}$is generated at $20 \mathrm{~K}$ then warmed to $120 \mathrm{~K}$, an increase is observed in the $850 \mathrm{~nm} \mathrm{Chl}_{\mathrm{Z}}^{+}$signal at the expense of the $\mathrm{Car}^{+}$(51). These latter observations have been interpreted in terms of an oxidation of $\mathrm{Chl}_{Z}$ by $\mathrm{Car}^{+}$in a thermally activated process. Hanley et al. (51) have argued that because cyt $b_{559}$ can be oxidized at $20 \mathrm{~K}$, whereas $\mathrm{Chl}_{\mathrm{Z}}$ cannot (in the presence of cyt $\mathrm{b}_{559}{ }^{+}$), then cyt $\mathrm{b}_{559}$ and $\mathrm{Chl}_{\mathrm{Z}}$ are located on different branches of the oxidation pathway and compete for the oxidizing equivalent on $\mathrm{Car}^{+}$at higher temperatures (Figure 6B). Tracewell et al. (123) were, however, able to observe some oxidation of $\mathrm{Chl}_{\mathrm{Z}}$ at $20 \mathrm{~K}$ and thus consider the question of a parallel (Figure $6 B$ ) or series (Figure 6A) connection for $\mathrm{Chl}_{\mathrm{Z}}$ and cyt $\mathrm{b}_{559}$ to $\mathrm{Car}^{+}$to be open.

There has been some controversy regarding the identity of $\mathrm{Chl}_{z}$. Perturbations of Resonance Raman spectra of $\mathrm{Chl}_{Z}^{+}$in site-directed mutations at D1-His118 in Synechocystis 6803 led to the conclusion that this residue coordinated $\mathrm{Chl}_{Z}(111)$. In contrast, observations by Ruffle et al. (96) of perturbations in the chlorophyll fluorescence yield caused by mutations at D2-His117 in Chlamydomonas and the spin relaxation measurements by Shigemori et al. (107) that yield a 29- $\AA$ distance between $\mathrm{Y}_{\mathrm{D}^{*}}$ and $\mathrm{Chl}_{\mathrm{Z}}$ both argue instead for coordination of $\mathrm{Chl}_{\mathrm{Z}}$ by D2-His117. The demonstration by Tracewell et al. (123) of $\mathrm{Chl}_{\mathrm{Z}}$ oxidation at $814 \mathrm{~nm}$ only in Synechocystis led these authors to assign this oxidized chlorophyll to $\mathrm{Chl}_{\mathrm{ZD} 1}^{+}$ (coordinated by D1-His118). The observation of $\mathrm{Chl}^{+}$absorption at $817 \mathrm{~nm}$ and at $850 \mathrm{~nm}$ in spinach led to the assignment of the latter to $\mathrm{Chl}_{\mathrm{ZD} 2}^{+}$(coordinated by D2-His117).

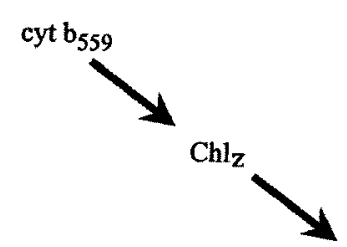

$\mathbf{A}$
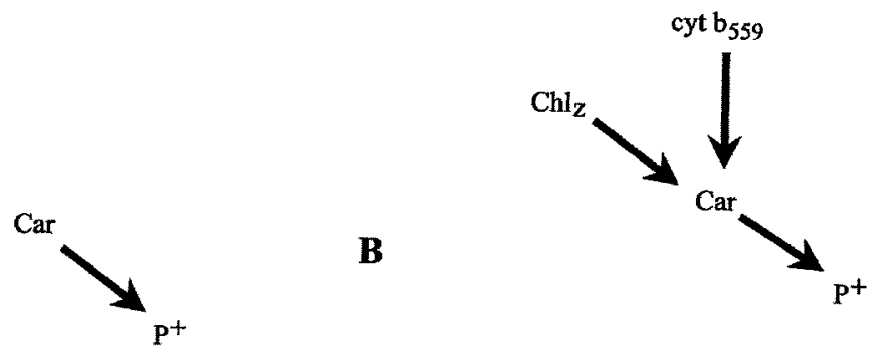

Figure 6 Two alternative models for the donor-side oxidative pathway that include Car, $\mathrm{Chl}_{Z}$, and cyt $\mathrm{b}_{559}$. In model $\mathrm{A}(123), \mathrm{Chl}_{\mathrm{Z}}$ and cyt $\mathrm{b}_{559}$ are connected in series to $\mathrm{Car}^{+}$. In model B (51), $\mathrm{Chl}_{\mathrm{Z}}$ and cyt $\mathrm{b}_{559}$ are parallel donors to $\mathrm{Car}^{+}$. 
The X-ray crystal structure of PSII has placed cyt $b_{559}$ much closer to D2-His 117 (Chl $\left.\mathrm{ZD}_{\mathrm{Z} 2}\right)$ than to D1-His118 (Chl $\left.\mathrm{ZD}_{\mathrm{Z} 1}\right)$ (Figure 1). Regardless of whether $\mathrm{Chl}_{Z}$ and $c y t \mathrm{~b}_{559}$ form a linear or branched pathway (Figure 6), it would still appear that $\mathrm{Chl}_{\mathrm{ZD} 2}$ is far more apt to compete with or to oxidize the cyt $\mathrm{b}_{559}$ present in the crystal structure. The reduction of cyt $\mathrm{b}_{559}$ by plastoquinol (146) and, more particularly, by $\mathrm{Q}_{\mathrm{B}} \mathrm{H}_{2}$ (or $\mathrm{Q}_{\mathrm{B}}^{-}$) (14) would also be more consistent with the interaction of this cytochrome with the $\mathrm{D} 2$ side components.

There has been considerable controversy over the years as to whether there are one or two cyt $b_{559}$ associated with PSII [for review see (110)]. One possible solution to this debate is that there are two cyt $b_{559}$ in thylakoid membranes but one is readily lost following detergent treatment. What remains then in the X-ray structure is the more tightly bound of the two. Consequently it may be that there are two pathways symmetrically arranged within the reaction center, both of which are capable of oxiding cyt $b_{559}$. Alternatively, it may be that only the D2 side pathway truly does cyclic electron transfer when the main donor side pathway is blocked. This would leave the D1 side to generate $\mathrm{Chl}_{\mathrm{ZD} 1}^{+}$, which would quench excitation energy, consistent with the observations of Schweitzer \& Brudvig [(106), also see (56)].

\section{REEVALUATION OF ENERGETICS}

Although a fairly clear and solid picture of the relative position and role of the different PSII cofactors has recently emerged, the energetic picture of PSII is more tenuous. This is, at least partly, attributed to the fact that, at variance with its bacterial homologues in which most of the component reduction potentials are accessible to direct redox titration, in PSII only three among the nine potentials have been directly measured (the Pheo/Pheo ${ }^{-}, \mathrm{Q}_{\mathrm{A}} / \mathrm{Q}_{\mathrm{A}}^{-}$, and $\mathrm{Y}_{\mathrm{D}}{ }^{\bullet} / \mathrm{Y}_{\mathrm{D}}$ couples). The determination of the free-energy changes associated with the successive electron transfer reactions has, however, allowed the estimation of reduction potentials that could not be directly determined by titration [see $(27,89,121)$ for reviews of the currently accepted values of the $\mathrm{P}^{+} / \mathrm{P}, \mathrm{Y}_{\mathrm{Z}} / \mathrm{Y}_{\mathrm{Z}}, \mathrm{S}_{1} / \mathrm{S}_{0}, \mathrm{~S}_{2} / \mathrm{S}_{1}, \mathrm{~S}_{3} / \mathrm{S}_{2}$, and $\mathrm{S}_{0} / \mathrm{S}_{3}$ couples]. In fact, all of the energetic relations within PSII rely on the determination of the reduction potential of the $\mathrm{Pheo} / \mathrm{Pheo}^{-}$couple $[-640 \mathrm{mV}(59)]$ and the assumption that the energy level of the $\mathrm{P}^{+} \mathrm{Pheo}^{-}$state is defined relative to this reduction potential. This latter hypothesis led Klimov et al. (59) to estimate the reduction potential of the $\mathrm{P}^{+} / \mathrm{P}$ couple to be approximately $1.12 \mathrm{~V}(-0.64-0.07+1.83)$ from the free-energy change associated with charge separation $(-70 \mathrm{meV})$ and the singletsinglet difference energy between $\mathrm{P}$ and $\mathrm{P}^{*}(1.83 \mathrm{eV})$. The midpoint potential of the $\mathrm{P}^{+} / \mathrm{P}$ couple has been then used as a reference to estimate the other reduction potentials from measured equilibrium constants. There is growing evidence that our current view of PSII energetics could be erroneous and may require revision. As the reduction potential of the $\mathrm{Pheo}_{\mathrm{A}} / \mathrm{Pheo}_{\mathrm{A}}^{-}$couple is more negative than that of the $\mathrm{Q}_{\mathrm{A}} / \mathrm{Q}_{\mathrm{A}}^{-}$couple, the equilibrium redox titration of $\mathrm{Pheo}_{\mathrm{A}}$ is inevitably performed 
in the presence of $\mathrm{Q}_{\mathrm{A}}^{-}$. Above, we discuss the consequences of the redox state of $\mathrm{Q}_{\mathrm{A}}$ on the rate of $\mathrm{P}^{+} \mathrm{Pheo}^{-}$radical pair decay, i.e., the significantly increased rate in the presence of $\mathrm{Q}_{A}^{-}$with respect to $\mathrm{Q}_{\mathrm{A}} \mathrm{H}_{2}$. Gibasiewicz et al. (41) recently estimated the electrostatic interaction between $\mathrm{Q}_{\mathrm{A}}^{-}$and $\mathrm{Pheo}^{-}$to be $\sim 90 \mathrm{mV}$. Thus the energy level of the $\mathrm{P}^{+} \mathrm{Pheo}^{-}$should be at least $90 \mathrm{mV}$ more positive than predicted by the equilibrium midpoint potential of the $\mathrm{Pheo} / \mathrm{Pheo}^{-}$couple. Similarly, an electrostatic interaction between $\mathrm{P}^{+}$and $\mathrm{Pheo}^{-}$could stabilize the radical pair and further decrease its energy level. Indeed, van Gorkom (132) estimated the free energy difference between $\mathrm{P}^{+} \mathrm{Q}_{\mathrm{A}}^{-}$and $\mathrm{P}^{+} \mathrm{Pheo}^{-}$to be $340 \mathrm{mV}$, i.e., approximately $260 \mathrm{mV}$ smaller than expected from the difference in midpoint potentials. If indeed the energy of the $\mathrm{P}^{+} \mathrm{Pheo}^{-}$radical pair is closer to that of $\mathrm{P}^{+} \mathrm{Q}_{\mathrm{A}}^{-}$than previously estimated, then an immediate consequence of this conclusion would be the upward revision of all of the reduction potentials (except for $Q_{A} / Q_{A}^{-}$and $Y_{D}{ }^{\bullet} Y_{D}$ ), including that of the $\mathrm{P}^{+} / \mathrm{P}$ couple, which determines the available driving force for water splitting.

\section{CONCLUSION}

There are a number of fundamental ways in which the view of PSII function is being altered by $(a)$ the newly developing three-dimensional structure of the PSII core complexes, $(b)$ biochemical chromophore replacement, $(c)$ analysis of sitedirected mutations, and $(d)$ new kinetic and spectroscopic methods. In this review, we mention that energy transfer and the electron transfer pathways involving Car, $\mathrm{Chl}_{\mathrm{Z}}$, and cyt $\mathrm{b}_{559}$ are undergoing intense reevaluation in light of new structural and kinetic information. As in the bacterial reaction centers, the three-dimensional structure likely will allow a better appreciation of how electrostatic interactions contribute to the energetics of the charge-separated states. Although not presently the case, the PSII X-ray structure will ultimately provide a great deal more assurance as to the location of the amino acid side chains of the component polypeptides, critical for the construction and interpretation of site-directed mutations. The intersection of all of these methods will provide a solid foundation for examining questions regarding the role of the protein in the function and assembly of the $\mathrm{Mn}$ cluster and other cofactors and the mechanisms of proton-coupled electron transfer; investigations whose impact extends well beyond the domain of photosynthesis.

\section{ACKNOWLEDGMENTS}

Support by the Central Research and Development Department of E. I. du Pont de Nemours \& Co., the NRICGP/USDA (97-35306-4882) (B.A.D.), and the Centre National de la Recherche Scientifique (F.R.) is gratefully acknowledged. We are also grateful to James Bautista, R. David Britt, Kristy Campbell, Dee Force, and Andy Pascal whose unpublished work is mentioned in the text. We also thank James Bautista for his help with the figures. This paper is contribution No. 8261 of the Central Research and Development Department, E. I. du Pont de Nemours \& Co. 


\section{Visit the Annual Reviews home page at www.annualreviews.org}

\section{LITERATURE CITED}

1. Ahlbrink R, Haumann M, Cherepanov D, Boegershausen O, Mulkidjanian A, Junge W. 1998. Function of tyrosine $\mathrm{Z}$ in water oxidation by photosystem II: electrostatical promotor instead of hydrogen abstractor. Biochemistry 37:1131-42

2. Ananyev GM, Sakiyan I, Diner BA, Dismukes GC. 2002. A functional role for tyrosine-D in assembly of the inorganic core of the water oxidase complex of photosytem II and the kinetics of water oxidation. Biochemistry 41:974-80

3. Barter LMC, Bianchietti M, Jeans C, Schilstra MJ, Hankamer B, et al. 2001. Relationship between excitation energy transfer, trapping, and antenna size in photosystem II. Biochemistry 40:4026-34

4. Beekman LMP, van Mourik F, Jones MR, Visser HM, Hunter CN, van Grondelle R. 1994. Trapping kinetics in mutants of the photosynthetic purple bacterium Rhodobacter sphaeroides: influence of the charge separation rate and consequences for the rate-limiting step in the light-harvesting process. Biochemistry 33:314347

5. Berthold DA, Babcock GT, Yocum CF. 1981. A highly resolved, oxygen-evolving photosystem II preparation from spinach thylakoid membranes. EPR and electrontransport properties. FEBS Lett. 134:23134

6. Blomberg MRA, Siegbahn PEM, Styring S, Babcock GT, Aakermark B, Korall P. 1997. A quantum chemical study of hydrogen abstraction from manganesecoordinated water by a tyrosyl radical: a model for water oxidation in photosystem II. J. Am. Chem. Soc. 119:8285-92

7. Boerner RJ, Bixby KA, Nguyen AP, Noren GH, Debus RJ, Barry BA. 1993. Removal of stable tyrosine radical $\mathrm{D}^{+}$affects the structure or redox properties of tyrosine $\mathrm{Z}$ in manganese-depleted pho- tosystem II particles from Synechocystis 6803. J. Biol. Chem. 268:1817-23

8. Booth PJ, Crystall B, Giorgi LB, Barber J, Klug DR, Porter G. 1990. Thermodynamic properties of D1/D2/cytochrome $\mathrm{b}_{559}$ reaction centers investigated by timeresolved fluorescence measurements. Biochim. Biophys. Acta 1016:141-52

9. Borg DC, Fajer J, Felton RH, Dolphin D. 1970. Pi-cation radical of chlorophyll-a. Proc. Natl. Acad. Sci. USA 67:813-20

10. Bosch MK, Proskuryakov II, Gast P, Hoff AJ. 1996. Time-resolved EPR study of the primary donor triplet in D1-D2-cyt $b_{559}$ complexes of photosystem II: temperature dependence of spin-lattice relaxation. $J$. Phys. Chem. 100:2384-90

11. Braun P, Greenberg BM, Scherz A. 1990. D1-D2-cytochrome $b_{559}$ complex from the aquatic plant Spirodela oligorrhiza: correlation between complex integrity, spectroscopic properties, photochemical activity, and pigment composition. Biochemistry 29:10376-87

12. Briantais J-M, Dacosta J, Goulas Y, Ducruet J-M, Moya I. 1996. Heat stress induces in leaves an increase of the minimum level of chlorophyll fluorescence, Fo: a time-resolved analysis. Photosynth. Res. 48:189-96

13. Britt RD. 1996. Oxygen evolution. In Oxygenic Photosynthesis: The Light Reactions, ed. DR Ort, CF Yocum, pp. 137-64. Dordrecht: Kluwer Acad.

14. Buser CA, Diner BA, Brudvig GW. 1992. Photooxidation of cytochrome $b_{559}$ in oxygen-evolving photosystem II. Biochemistry 31:11449-59

14a. Bylina EJ, Youvan DC. 1988. Directed mutations affecting spectroscopic and electron transfer properties of the primary donor in the photosynthetic reaction center. Proc. Natl. Acad. Sci. USA 85:722630 
15. Bylina EJ, Kirmaier C, McDowell L, Holten D, Youvan DC. 1988. Influence of an amino-acid residue on the optical properties and electron transfer dynamics of a photosynthetic reaction center complex. Nature 336:182-84

16. Campbell KA, Peloquin JM, Diner BA, Tang X-S, Chisholm DA, Britt RD. 1997. The tau-nitrogen of D2 histidine 189 is the hydrogen bond donor to the tyrosine radical $\mathrm{Y}_{\mathrm{D}}$ of photosystem II. J. Am. Chem. Soc. 119:4787-88

17. Chirino AJ, Lous EJ, Huber M, Allen JP, Schenck CC, et al. 1994. Crystallographic analyses of site-directed mutants of the photosynthetic reaction center from Rhodobacter sphaeroides. Biochemistry 33:4584-93

18. Clayton RK, Yamamoto T. 1976. Photochemical quantum efficiency and absorption spectra of reaction centers from Rhodopseudomonas sphaeroides at low temperature. Photochem. Photobiol. 24: 67-70

19. Cramer WA, Theg SM, Widger WR. 1986. On the structure and function of cytochrome $b_{559}$. Photosynth. Res. 10:393-403

20. Danielius RV, Satoh K, van Kan PJM, Plijter JJ, Nuijs AM, van Gorkom HJ. 1987. The primary reaction of photosystem II in the D1-D2-cytochrome $b_{559}$ complex. FEBS Lett. 213:241-44

21. Dau H, Sauer K. 1996. Exciton equilibration and photosystem II exciton dynamics - a fluorescence study on photosystem II membrane particles of spinach. Biochim. Biophys. Acta 1273:175-90

22. Debus RJ. 2000. The polypeptides of photosystem II and their influence on manganotyrosyl-based oxygen evolution. In Metal Ions in Biological Systems, ed. A Sigel, H Sigel, pp. 657-711. New York: Dekker

23. Debus RJ. 2001. Amino acid residues that modulate the properties of tyrosine $\mathrm{Y}_{\mathrm{Z}}$ and the manganese cluster in the water oxidizing complex of photosystem II. Biochim. Biophys. Acta 1503:164-86
24. Dekker JP, van Grondelle R. 2000. Primary charge separation in photosystem II. Photosynth. Res. 63:195-208

25. Den Blanken HJ, Hoff AJ, Jongenelis APJM, Diner BA. 1983. High-resolution triplet-minus-singlet absorbance difference spectrum of photosystem II particles. FEBS Lett. 157:21-27

26. Diner BA. 2001. Amino acid residues involved in the coordination and assembly of the manganese cluster of photosystem II. Proton-coupled electron transport of the redox-active tyrosines and its relationship to water oxidation. Biochim. Biophys. Acta 1503:147-63

27. Diner BA, Babcock GT. 1996. Structure, dynamics, and energy conversion efficiency in photosystem II. In Oxygenic Photosynthesis: The Light Reactions, ed. D Ort, C Yocum, pp. 213-47. Dordrecht: Kluwer Acad.

28. Diner BA, Force DA, Randall DW, Britt RD. 1998. Hydrogen bonding, solvent exchange, and coupled proton and electron transfer in the oxidation and reduction of redox-active tyrosine $\mathrm{Y}_{\mathrm{Z}}$ in Mn-depleted core complexes of Photosystem II. Biochemistry 37:17931-43

29. Diner BA, Nixon PJ. 1998. Evidence for D1-His190 as the proton acceptor implicated in the oxidation of redox-active tyrosine $Y_{Z}$ of PSII. See Ref. 38a, pp. 1177-80

30. Diner BA, Schlodder E, Nixon PJ, Coleman WJ, Rappaport F, et al. 2001. Sitedirected mutations at D1-His198 and D2His 197 of photosystem II in Synechocystis PCC 6803: sites of primary charge separation and cation and triplet stabilization. Biochemistry 40:9265-81

31. Diner BA, Tang X-S, Zheng M, Dismukes GC, Force DA, et al. 1995. Environment and function of the redox active tyrosines of photosystem II. In Photosynthesis: From Light to Biosphere, ed. P Mathis, pp. 229-34. Dordrecht: Kluwer Acad.

32. Donovan B, Walker LA II, Kaplan D, Bouvier M, Yocum CF, Sension RJ. 1997. Structure and function in the isolated 
reaction center complex of photosystem II. 1. Ultrafast fluorescence measurements of PSII. J. Phys. Chem. B 101:5232-38

33. Dorlet P, Xiong L, Sayre RT, Un S. 2001. High field EPR study of the pheophytin anion radical in wild type and D1-E130 mutants of photosystem II in Chlamydomonas reinhardtii. J. Biol. Chem. 276: 22313-16

34. Durrant JR, Giorgi LB, Barber J, Klug DR, Porter G. 1990. Characterization of triplet states in isolated photosystem II reaction centers: oxygen quenching as a mechanism for photodamage. Biochim. Biophys. Acta 1017:167-75

35. Durrant JR, Hastings G, Joseph DM, Barber J, Porter G, Klug DR. 1992. Subpicosecond equilibration of excitation energy in isolated photosystem II reaction centers. Proc. Natl. Acad. Sci. USA 89: 11632-36

36. Ermler U, Fritzsch G, Buchanan SK, Michel H. 1994. Structure of the photosynthetic reaction center from Rhodobacter sphaeroides at $2.65 \AA$ resolution: cofactors and protein-cofactor interactions. Structure 2:925-36

37. Faller P, Debus RJ, Brettel K, Sugiura M, Rutherford AW, Boussac A. 2001. Rapid formation of the stable tyrosyl radical in Photosystem II. Proc. Natl. Acad. Sci. USA 98:14368-73

38. Fleming GR, Martin JL, Breton J. 1988. Rates of primary electron transfer in photosynthetic reaction centers and their mechanistic implications. Nature 333: 190-92

38a. Garab G, ed. 1998. Photosynthesis: Mechanism and Effects. Dordrecht: Kluwer Acad.

39. Germano M, Shkuropatov AY, Permentier H, de Wijn R, Hoff AJ, et al. 2001. Pigment organization and their interactions in reaction centers of photosystem II: optical spectroscopy at $6 \mathrm{~K}$ of reaction centers with modified pheophytin composition. Biochemistry 40:11472-82

40. Germano M, Shkuropatov AY, Permen- tier H, Khatypov RA, Shuvalov VA, et al. 2000. Selective replacement of the active and inactive pheophytin in reaction centers of photosystem II by $13^{1}$-deoxo- $13^{1}$ hydroxy-pheophytin $a$ and comparison of their 6-K absorption spectra. Photosynth. Res. 64:189-98

41. Gibasiewicz K, Dobek A, Breton J, Leibl W. 2001. Modulation of primary radical pair kinetics and energetics in photosystem II by the redox state of the quinone electron acceptor $\mathrm{Q}_{\mathrm{A}}$. Biophys. J. 80: 1617-30

42. Giorgi LB, Nixon PJ, Merry SA, Joseph DM, Durrant JR, et al. 1996. Comparison of primary charge separation in the photosystem II reaction center complex isolated from wild-type and D1-130 mutants of the cyanobacterium Synechocystis PCC 6803. J. Biol. Chem. 271:2093-101

43. Goldsmith JO, King B, Boxer SG. 1996. $\mathrm{Mg}$ coordination by amino acid side chains is not required for assembly and function of the special pair in bacterial photosynthetic reaction centers. Biochemistry 35:2421-28

44. Greenfield SR, Seibert M, Govindjee, Wasielewski MR. 1997. Direct measurement of the effective rate constant for primary charge separation in isolated photosystem II reaction centers. J. Phys. Chem. B 101:2251-55

45. Greenfield SR, Seibert M, Wasielewski MR. 1999. Time-resolved absorption changes of the pheophytin $\mathrm{Q}_{\mathrm{X}}$ band in isolated photosystem II reaction centers at 7 $\mathrm{K}$ : energy transfer and charge separation. J. Phys. Chem. B 103:8364-74

46. Greenfield SR, Wasielewski MR. 1996. Excitation energy transfer and charge separation in the isolated photosystem II reaction center. Photosynth. Res. 48:83-97

47. Groot M-L, van Mourik F, Eijckelhoff C, van Stokkum IHM, Dekker JP, van Grondelle R. 1997. Charge separation in the reaction center of photosystem II studied as a function of temperature. Proc. Natl. Acad. Sci. USA 94:4389-94 
48. Groot M-L, Peterman EJG, van Kan PJM, van Stokkum IHM, Dekker JP, van Grondelle R. 1994. Temperature-dependent triplet and fluorescence quantum yields of the photosystem II reaction center described in a thermodynamic model. Biophys. J. 67:318-30

49. Hales BJ, Das Gupta A. 1979. Orientation of the bacteriochlorophyll triplet and the primary ubiquinone acceptor of Rhodospirillum rubrum in membrane multilayers determined by ESR spectroscopy. I. Biochim. Biophys. Acta 548:276-86

50. Hankamer B, Barber J, Boekema EJ. 1997. Structure and membrane organization of photosystem II in green plants. Annu. Rev. Plant Physiol. Plant Mol. Biol. 48: 641-71

51. Hanley J, Deligiannakis Y, Pascal A, Faller P, Rutherford AW. 1999. Carotenoid oxidation in photosystem II. Biochemistry 38:8189-95

52. Hays AM, Vassiliev IR, Golbeck JH, Debus RJ. 1998. Role of D1-His190 in proton-coupled electron transfer reactions in photosystem II: a chemical complementation study. Biochemistry 37:11352-65

53. Hienerwadel R, Boussac A, Breton J, Diner BA, Berthomieu C. 1997. Fourier transform infrared difference spectroscopy of photosystem II tyrosine D using site-directed mutagenesis and specific isotope labeling. Biochemistry 36:1471223

54. Hillmann B, Brettel K, van Mieghem F, Kamlowski A, Rutherford AW, Schlodder E. 1995. Charge recombination reactions in photosystem II. 2. Transient absorbance difference spectra and their temperature dependence. Biochemistry 34:4814-27

55. Hillmann B, Schlodder E. 1995. Electron transfer reactions in Photosystem II core complexes from Synechococcus at low temperature-difference spectrum of $\mathrm{P}_{680}+\mathrm{Q}_{\mathrm{A}}^{-} / \mathrm{P} 680 \mathrm{Q}_{\mathrm{A}}$ at 77 K. Biochim. Biophys. Acta 1231:76-88

56. Horton P, Ruban AV, Walters RG. 1996. Regulation of light harvesting in green plants. Annu. Rev. Plant Physiol. Plant Mol. Biol. 47:655-84

56a. Ikeuchi M, Inoue Y. 1988. A new photosystem II reaction center component (4.8 $\mathrm{kDa}$ protein) encoded by chloroplast genome. FEBS Lett. 241:99-104

57. Jankowiak R, Tang D, Small GJ, Seibert M. 1989. Transient and persistent hole burning of the reaction center of photosystem II. J. Phys. Chem. 93:1649-54

58. Kamlowski A, Frankemöller L, van der Est A, Stehlik D, Holzwarth A. 1996. Evidence for the delocalization of the triplet state ${ }^{3} \mathrm{P} 680$ in the D1D2cyt $b_{559}$-complex of photosystem II. Ber. Bunsenges. Phys. Chem. 100:2045-51

58a. Kirmaier C, Gaul D, DeBey R, Holten D, Schenck CC. 1991. Charge separation in a reaction center incorporating bacteriochlorophyll for photoactive bacteriopheophytin. Science 251:922-27

59. Klimov VV, Krasnovskii AA. 1981. Pheophytin as the primary electron acceptor in photosystem II reaction centers. Photosynthetica 15:592-609

60. Klug DR, Durrant JR, Barber J. 1998. The entanglement of excitation energy transfer and electron transfer in the reaction center of photosystem II. Philos. Trans. R. Soc. London Ser. A 356:449-64

61. Klug DR, Rech T, Joseph DM, Barber J, Durrant JR, Porter G. 1995. Primary processes in isolated Photosystem II reaction centers probed by magic angle transient absorption spectroscopy. Chem. Phys. 194:433-42

62. Konermann L, Gatzen G, Holzwarth AR. 1997. Primary processes and structure of the photosystem II reaction center. Part V. Modeling of the fluorescence kinetics of the D1-D2-cyt-b 559 complex at $77 \mathrm{~K} . J$. Phys. Chem. B 101:2933-44

63. Konermann L, Holzwarth AR. 1996. Analysis of the absorption spectrum of photosystem II reaction centers: temperature dependence, pigment assignment, and inhomogeneous broadening. Biochemistry $35: 829-42$ 
64. Konermann L, Yruela I, Holzwarth AR. 1997. Pigment assignment in the absorption spectrum of the photosystem II reaction center by site-selection fluorescence spectroscopy. Biochemistry 36:7498-502

65. Koulougliotis D, Innes JB, Brudvig GW. 1994. Location of chlorophyll $\mathrm{Z}_{\mathrm{Z}}$ in photosystem II. Biochemistry 33:11814-22

66. Krabben L, Schlodder E, Jordan R, Carbonera D, Giacometti G, et al. 2000. Influence of the axial ligands on the spectral properties of P700 of photosystem I: a study of site-directed mutants. Biochemistry 39:13012-25

67. Krishtalik LI. 1990. Activation energy of photosynthetic oxygen evolution: an attempt at theoretical analysis. Bioelectrochem. Bioenerg. 23:249-63

68. Kwa SLS, Eijckelhoff C, van Grondelle R, Dekker JP. 1994. Site-selection spectroscopy of the reaction center complex of photosystem II. 1. Triplet-minus-singlet absorption difference: search for a second exciton band of P680. J. Phys. Chem. 98:7702-11

69. Lin S, Taguchi AKW, Woodbury NW. 1996. Excitation wavelength dependence of energy transfer and charge separation in reaction centers from Rhodobacter sphaeroides: evidence for adiabatic electron transfer. J. Phys. Chem. 100:1706778

70. Lince MT, Vermaas W. 1998. Association of His117 in the D2 protein of photosystem II with a chlorophyll that affects excitation-energy transfer efficiency to the reaction center. Eur. J. Biochem. 256:595602

71. Mathis P, Breton J, Vermeglio A, Yates M. 1976. Orientation of the primary donor chlorophyll of Photosystem II in chloroplast membranes. FEBS Lett. 63:171-73

72. McGlynn SP, Azumi T, Kinoshita M. 1969. Molecular Spectroscopy of the Triplet State. Englewood Cliffs, NJ: Prentice Hall

73. Merry SAP, Kumazaki S, Tachibana Y, Joseph DM, Porter G, et al. 1996. Sub- picosecond equilibration of excitation energy in isolated photosystem II reaction centers revisited: time-dependent anisotropy. J. Phys. Chem. 100:10469-78

74. Merry SAP, Nixon PJ, Barter LMC, Schilstra M, Porter G, et al. 1998. Modulation of quantum yield of primary radical pair formation in photosystem II by site-directed mutagenesis affecting radical cations and anions. Biochemistry 37:17439-47

75. Michel H, Deisenhofer J. 1988. Relevance of the photosynthetic reaction center from purple bacteria to the structure of photosystem II. Biochemistry 27:1-7

76. Moënne-Loccoz P, Robert B, Lutz M. 1989. A resonance Raman characterization of the primary electron acceptor in photosystem II. Biochemistry 28:3641-45

77. Mueller MG, Hucke M, Reus M, Holzwarth AR. 1996. Primary processes and structure of the photosystem II reaction center 4. Low-intensity femtosecond transient absorption spectra of D1-D2-cyt$\mathrm{b}_{559}$ reaction centers. J. Phys. Chem. 100: 9527-36

77a. Nanba O, Satoh K. 1987. Isolation of a Photosystem II reaction center consisting of D-1 and D-2 polypeptides and cytochrome b-559. Proc. Natl. Acad. Sci. USA 84:109-12

78. Noguchi T, Inoue Y, Satoh K. 1993. FTIR studies on the triplet state of P680 in the photosystem II reaction center: triplet equilibrium within a chlorophyll dimer. Biochemistry 32:7186-95

79. Noguchi T, Mitsuka T, Inoue Y. 1994. Fourier transform infrared spectrum of the radical cation of beta-carotene photoinduced in photosystem II. FEBS Lett. 356:179-82

80. Noguchi T, Tomo T, Inoue Y. 1998. Fourier transform infrared study of the cation radical of P680 in the photosystem II reaction center: evidence for charge delocalization on the chlorophyll dimer. Biochemistry 37:13614-25

81. Noguchi T, Tomo T, Kato C. 2001. Triplet 
formation on a monomeric chlorophyll in the photosystem II reaction center as studied by time-resolved infrared spectroscopy. Biochemistry 40:2176-85

82. O'Malley PJ. 1998. Hybrid density functional studies of the oxidation of phenolimidazole hydrogen-bonded complexes: a model for tyrosine oxidation in oxygenic photosynthesis. J. Am. Chem. Soc. 120:11732-37

83. Pecoraro VL, Baldwin MJ, Caudle MT, Hsieh W-Y, Law NA. 1998. A proposal for water oxidation in photosystem II. Pure Appl. Chem. 70:925-29

84. Peloquin JM, Williams JC, Lin X, Alden RG, Taguchi AKW, et al. 1994. Timedependent thermodynamics during early electron transfer in reaction centers from Rhodobacter sphaeroides. Biochemistry 33:8089-100

85. Peterman EJG, Van Amerongen $\mathrm{H}$, van Grondelle R, Dekker JP. 1998. The nature of the excited state of the reaction center of photosystem II of green plants: a high-resolution fluorescence spectroscopy study. Proc. Natl. Acad. Sci. USA 95:6128-33

86. Rappaport F, Lavergne J. 1991. Proton release during successive oxidation steps of the photosynthetic water oxidation process: stoichiometries and $\mathrm{pH}$ dependence. Biochemistry 30:10004-12

87. Rappaport F, Lavergne J. 1997. Charge recombination and proton transfer in manganese-depleted photosystem II. Biochemistry 36:15294-302

88. Renger G. 1992. Energy transfer and trapping in photosystem II. In The Photosystems: Structure, Function and Molecular Biology, ed. J Barber, pp. 45-99. Amsterdam: Elsevier

89. Renger G. 2001. Photosynthetic water oxidation to molecular oxygen: apparatus and mechanism. Biochim. Biophys. Acta 1503:210-28

90. Rhee K-H. 2001. Photosystem II: the solid structural era. Annu. Rev. Biophys. Biomol. Struct. 30:307-28
91. Rhee K-H, Morris EP, Barber J, Kuhlbrandt W. 1998. Three-dimensional structure of the plant photosystem II reaction centre at 8-Å resolution. Nature 396:28386

92. Rhee K-H, Morris EP, Zheleva D, Hankamer B, Kuhlbrandt W, Barber J. 1997. Two-dimensional structure of plant photosystem II at 8-Å resolution. Nature 389: 522-26

93. Rigby SEJ, Nugent JHA, O’Malley PJ. 1994. ENDOR and Special Triple Resonance studies of chlorophyll cation radicals in photosystem II. Biochemistry 33: 10043-50

94. Rodriguez ID, Chandrashekar TK, Babcock GT. 1987. ENDOR characterization of $\mathrm{H}_{2} \mathrm{O} / \mathrm{D}_{2} \mathrm{O}$ exchange in the $\mathrm{D}^{+} \mathrm{Z}^{+}$radical in photosynthesis. In Progress in Photosynthesis Research, ed. J Biggins, pp. 471-74. Dordrecht: Martinus Nijhoff

95. Roelofs TA, Lee $\mathrm{CH}$, Holzwarth AR. 1992. Global target analysis of picosecond chlorophyll fluorescence kinetics from pea chloroplasts: a new approach to the characterization of the primary processes in photosystem II a and b units. Biophys. J. 61:1147-63

96. Ruffle S, Hutchison R, Sayre RT. 1998. Mutagenesis of the symmetry related H117 residue in the photosystem II D2 protein of Chlamydomonas: implications for energy transfer from accessory chlorophylls. Photosynth.: Mech. Eff., Proc. Int. Congr. Photosynth., 11th, 2:1013-16

97. Ruffle SV, Donnelly D, Blundell TL, Nugent JHA. 1992. A three-dimensional model of the photosystem II reaction center of Pisum sativum. Photosynth. Res. 34:287-300

98. Rutherford AW. 1988. Photosystem II, the oxygen evolving photosystem. In Light Energy Transduction in Photosynthesis: Higher Plant and Bacterial Models, ed. SE Stevens, DA Bryant, pp. 163-77. Rockville, MD: Am. Soc. Plant Physiol.

99. Rutherford AW, Nitschke W. 1996. Photosystem II and the quinone-iron-containing 
reaction centers: comparisons and evolutionary perspectives. In Origin and Evolution of Biological Energy Conversion, ed. H Baltscheffsky, pp. 143-75. New York: $\mathrm{VCH}$

100. Rutherford AW, Paterson DR, Mullet JE. 1981. A light-induced spin-polarized triplet detected by EPR in photosystem II reaction centers. Biochim. Biophys. Acta 635:205-14

101. Sarcina M, Breton J, Nabedryk E, Diner BA, Nixon PJ. 1998. FTIR studies on the P680 cation and triplet states in WT and mutant PSII reaction centers of Synechocystis 6803 . See Ref. 38a, pp. 1053-56

102. Schatz GH, Brock H, Holzwarth AR. 1988. Kinetic and energetic model for the primary processes in photosystem II. Biophys. J. 54:397-405

103. Schelvis JPM, van Noort PI, Aartsma TJ, van Gorkom HJ. 1994. Energy transfer, charge separation and pigment arrangement in the reaction center of photosystem II. Biochim. Biophys. Acta 1184:242-50

104. Schenck CC, Diner B, Mathis P, Satoh K. 1982. Flash-induced carotenoid radical cation formation in photosystem II. Biochim. Biophys. Acta 680:216-27

105. Schulz C, Muh F, Beyer A, Jordan R, Schlodder E, Lubitz W. 1998. Investigation of Rhodobacter sphaeroides reaction center mutants with changed ligands to the primary donor. See Ref. 38a, pp. 767-70

106. Schweitzer RH, Brudvig GW. 1997. Fluorescence quenching by chlorophyll cations in photosystem II. Biochemistry 36:11351-59

107. Shigemori K, Hara H, Kawamori A, Akabori K. 1998. Determination of distances from tyrosine $\mathrm{D}$ to $\mathrm{Q}_{\mathrm{A}}$ and chlorophyll $\mathrm{Z}$ in photosystem II studied by $2^{\prime}+1^{\prime}$ pulsed EPR. Biochim. Biophys. Acta 1363:18798

108. Shkuropatov AY, Khatypov RA, Shkuropatova VA, Zvereva MG, Owens TG, Shuvalov VA. 1999. Reaction centers of photosystem II with a chemically modified pigment composition: exchange of pheo- phytins with $13^{1}$-deoxo- $13^{1}$-hydroxypheophytin $a$. FEBS Lett. 450:163-67

109. Shkuropatov AY, Khatypov RA, Volshchukova TS, Shkuropatova VA, Owens TG, Shuvalov VA. 1997. Spectral and photochemical properties of borohydridetreated D1-D2-cytochrome $\mathrm{b}_{559}$ complex of photosystem II. FEBS Lett. 420:17174

110. Stewart DH, Brudvig GW. 1998. Cytochrome $b_{559}$ of photosystem II. Biochim. Biophys. Acta 1367:63-87

111. Stewart DH, Cua A, Chisholm DA, Diner BA, Bocian DF, Brudvig GW. 1998. Identification of Histidine 118 in the D1 polypeptide of photosystem II as the axial ligand to chlorophyll $\mathrm{Z}_{\mathrm{Z}}$. Biochemistry 37:10040-46

112. Svensson B, Etchebest C, Tuffery P, van Kan P, Smith J, Styring S. 1996. A model for the photosystem II reaction center core including the structure of the primary donor P680. Biochemistry 35:14486-502

113. Szalai VA, Kuhne H, Lakshmi KV, Brudvig GW. 1998. Characterization of the interaction between manganese and tyrosine $\mathrm{Z}$ in acetate-inhibited photosystem II. Biochemistry 37:13594-603

114. Takahashi Y, Hansson O, Mathis P, Satoh K. 1987. Primary radical pair in the photosystem II reaction center. Biochim. Biophys. Acta 893:49-59

115. Tan Q, Kuciauskas D, Lin S, Stone S, Moore AL, Moore TA, Gust D. 1997. Dynamics of photoinduced electron transfer in a carotenoid-porphyrin-dinitronaphthalenedicarboximide molecular triad. J. Phys. Chem. B 101:5214-23

116. Tang X-S, Randall DW, Force DA, Diner BA, Britt RD. 1996. Manganese-tyrosine interaction in the photosystem II oxygenevolving complex. J. Am. Chem. Soc. 118:7638-39

117. Telfer A, Lendzian F, Schlodder E, Barber J, Lubitz W. 1998. ENDOR and transient absorption studies of $\mathrm{P} 680^{+}$and other cation radicals in PSII reaction centers before and after inactivation of secondary 
electron donors. See Ref. 38a, pp. 106164

118. Tetenkin VL, Gulyaev BA, Seibert M, Rubin AB. 1989. Spectral properties of stabilized D1/D2/cytochrome $b_{559}$ photosystem II reaction center complex. Effects of Triton X-100, the redox state of pheophytin, and beta-carotene. FEBS Lett. 250:459-63

119. Tiede DM, Dutton PL. 1981. Orientation of the primary quinone of bacterial photosynthetic reaction centers contained in chromatophore and reconstituted membranes. Biochim. Biophys. Acta 637:27890

120. Tommos C, Babcock GT. 1998. Oxygen production in nature: a light-driven metalloradical enzyme process. Acc. Chem. Res. 31:18-25

121. Tommos C, Babcock GT. 2000. Proton and hydrogen currents in photosynthetic water oxidation. Biochim. Biophys. Acta 1458:199-219

122. Tommos C, McCracken J, Styring S, Babcock GT. 1998. Stepwise disintegration of the photosynthetic oxygen-evolving complex. J. Am. Chem. Soc. 120:10441-52

123. Tracewell CA, Cua A, Stewart DH, Bocian DF, Brudvig GW. 2001. Characterization of carotenoid and chlorophyll photooxidation in photosystem II. Biochemistry 40:193-203

124. Tracewell CA, Vrettos JS, Bautista JA, Frank HA, Brudvig GW. 2001. Carotenoid photooxidation in photosystem II. Arch. Biochem. Biophys. 385:61-69

125. Trebst A. 1986. The topology of plastoquinone and herbicide binding peptides of photosystem II in the thylakoid membrane. Z. Naturforsch. Teil C. 41:240-45

126. Vacha F, Joseph DM, Durrant JR, Telfer A, Klug DR, et al. 1995. Photochemistry and spectroscopy of a five-chlorophyll reaction center of photosystem II isolated by using a $\mathrm{Cu}$ affinity column. Proc. Natl. Acad. Sci. USA 92:2929-33

127. Valkunas L, Liuolia V, Dekker JP, van Grondelle R. 1995. Description of en- ergy migration and trapping in photosystem I by a model with two distance scaling parameters. Photosynth. Res. 43:14954

128. van Brederode ME, Jones MR, van Mourik F, van Stokkum IHM, van Grondelle R. 1997. A new pathway for transmembrane electron transfer in photosynthetic reaction centers of Rhodobacter sphaeroides not involving the excited special pair. Biochemistry 36:6855-61

129. van Brederode ME, van Mourik F, van Stokkum IHM, Jones MR, van Grondelle R. 1999. Multiple pathways for ultrafast transduction of light energy in the photosynthetic reaction center of Rhodobacter sphaeroides. Proc. Natl. Acad. Sci. USA 96:2054-59

130. van Brederode ME, van Stokkum IHM, Katilius E, van Mourik F, Jones MR, van Grondelle R. 1999. Primary charge separation routes in the $\mathrm{B}_{\mathrm{Chl}}: \mathrm{B}_{\text {Phe }}$ heterodimer reaction centers of Rhodobacter sphaeroides. Biochemistry 38:7545-55

131. van der Vos R, van Leeuwen PJ, Braun P, Hoff AJ. 1992. Analysis of the optical absorbance spectra of D1-D2-cytochrome $\mathrm{b}_{559}$ complexes by absorbance-detected magnetic resonance. Structural properties of P680. Biochim. Biophys. Acta 1140:184-98

132. van Gorkom HJ. 1985. Electron transfer in photosystem II. Photosynth. Res. 6:97112

133. van Grondelle R, Dekker JP, Gillbro T, Sundstrom V. 1994. Energy transfer and trapping in photosynthesis. Biochim. Biophys. Acta 1187:1-65

134. van Kan PJM, Otte SCM, Kleinherenbrink FAM, Nieveen MC, Aartsma TJ, van Gorkom HJ. 1990. Time-resolved spectroscopy at $10 \mathrm{~K}$ of the photosystem II reaction center; deconvolution of the red absorption band. Biochim. Biophys. Acta 1020:146-52

135. van Mieghem FJE, Satoh K, Rutherford AW. 1991. A chlorophyll tilted $30^{\circ}$ relative to the membrane in the photosystem 
II reaction center. Biochim. Biophys. Acta 1058:379-85

136. Vasil'ev S, Diner B. 2000. Picosecond time-resolved fluorescence studies on excitation energy transfer in a Histidine 117 mutant of the D2 protein of photosystem II in Synechocystis 6803. Biochemistry 39:14211-18

137. Vasil'ev S, Orth P, Zouni A, Owens TG, Diner B. 2001. Excited-state dynamics in photosystem II: insights from the X-ray crystal structure. Proc. Natl. Acad. Sci. USA 98:8602-7

138. Vermaas WFJ, Ikeuchi M, Inoue Y. 1988. Protein composition of the photosystem II core complex in genetically engineered mutants of the cyanobacterium Synechocystis sp. PCC 6803. Photosynth. Res. 17:97-113

139. Visser HM, Groot M-L, van Mourik F, van Stokkum IHM, Dekker JP, van Grondelle R. 1995. Subpicosecond transient absorption difference spectroscopy on the reaction center of photosystem II: radical pair formation at 77 K. J. Phys. Chem. 99: 15304-9

140. Visser JWM, Rijgersberg CP, Gast P. 1977. Photooxidation of chlorophyll in spinach chloroplasts between 10 and $180^{\circ}$ K. Biochim. Biophys. Acta 460:36-46

141. Volk M, Gilbert M, Rousseau G, Richter M, Ogrodnik A, Michel-Beyerle M-E. 1993. Similarity of primary radical pair recombination in photosystem II and bacterial reaction centers. FEBS Lett. 336:35762

142. Vos MH, Breton J, Martin J-L. 1997. Electronic energy transfer within the hexamer cofactor system of bacterial reaction centers. J. Phys. Chem. B 101:9820-32

143. Wasielewski MR, Johnson DG, Govindjee, Preston C, Seibert M. 1989. Determination of the primary charge separation rate in photosystem II reaction centers at 15 K. Photosynth. Res. 22:89-99

144. Webber AN, Su H, Bingham SE, Kaess H, Krabben L, et al. 1996. Site-directed mutations affecting the spectroscopic characteristics and midpoint potential of the primary donor in photosystem I. Biochemistry 35:12857-63

145. Westphal KL, Tommos C, Cukier RI, Babcock GT. 2000. Concerted hydrogen-atom abstraction in photosynthetic water oxidation. Curr. Opin. Plant Biol. 3:236-42

146. Whitmarsh J, Cramer WA. 1978. A pathway for the reduction of cytochrome $\mathrm{b}_{559}$ by photosystem II in chloroplasts. Biochim. Biophys. Acta 501:83-93

147. Woodbury NW, Allen JP. 1995. The pathway, kinetics and thermodynamics of electron transfer in wild-type and mutant reaction centers of purple nonsulfur bacteria. In Anoxygenic Photosynthesis, ed. RE Blankenship, MT Madigan, CE Bauer, pp. 527-57. Dordrecht: Kluwer Acad.

148. Xiong J, Subramaniam S, Govindjee. 1998. A knowledge-based three-dimensional model of the photosystem II reaction center of Chlamydomonas reinhardtii. Photosynth. Res. 56:229-54

149. Zouni A, Witt H-T, Kern J, Fromme P, Krauss N, et al. 2001. Crystal structure of photosystem II from Synechococcus elongatus at 3.8-Å resolution. Nature 409: 739-43 


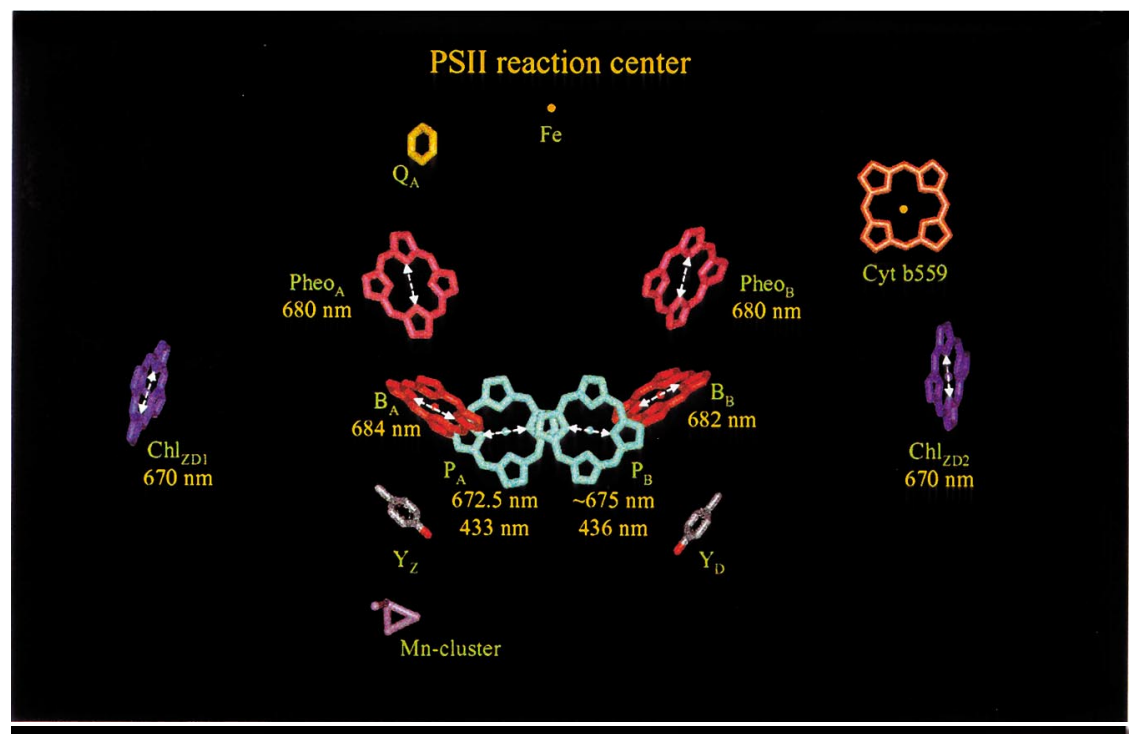

Rb. sphaeroides reaction center

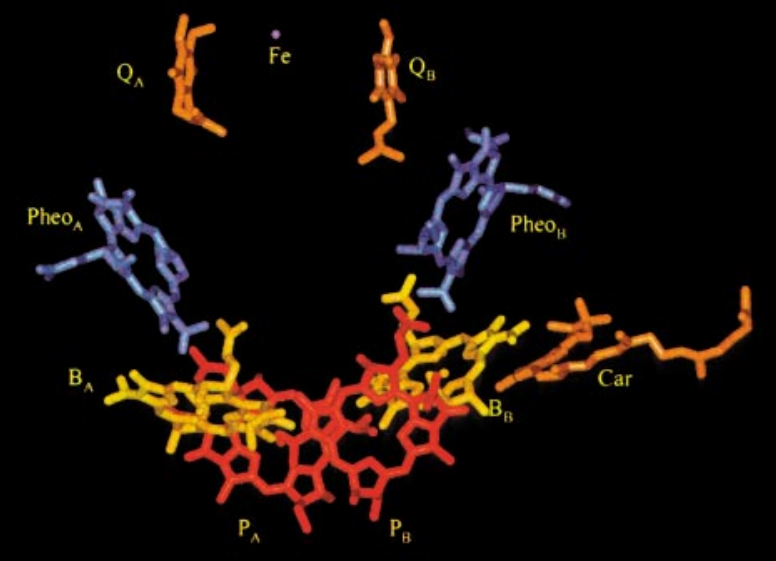

Figure 1 Redox active components of the Synechococcus elongatus Photosystem II [adapted from Reference (149)] and the $R b$. sphaeroides reaction centers [adapted from Reference (17)]. The view in both cases is in the plane of the membrane. A and B refer to the active branch and inactive branch components, respectively. The absorbance maxima for each of the chromophores in the Synechocystis PSII reaction center are indicated. The double-headed dashed arrows refer to the approximate orientation of the Qy transitions. 
A

Annual Review of Plant Biology

Volume 53, 2002

\section{CONTENTS}

Frontispiece-A. A. Benson

xii

Paving the Path, A. A. Benson

NEW INSIGHTS INTO THE REGULATION AND FUNCTIONAL

SignifiCANCE of Lysine Metabolism in Plants, Gad Galili

SHOOT AND Floral MERISTEM MaINTENANCE IN ARABIDOPSIS, Jennifer C. Fletcher

Nonselective Cation Channels in Plants, Vadim Demidchik, Romola Jane Davenport, and Mark Tester

ReVEaling the Molecular SeCRets of Marine Diatoms, Angela Falciatore and Chris Bowler

Abscission, DehisCence, AND Other CEll SePARATION PROCESSES, Jeremy A. Roberts, Katherine A. Elliott, and Zinnia H. Gonzalez-Carranza

Phytochelatins and Metallothioneins: Roles in Heavy Metal DETOXIFICATION AND HOMEOSTASIS, Christopher Cobbett and Peter Goldsbrough

VASCULAR TISSUE DIFFERENTIATION AND PATTERN FORMATION IN PlanTS, Zheng-Hua Ye

LOCAL AND LONG-RANGE Signaling PATHWAYS REgUlating Plant ResPonses to NitRATE, Brian G. Forde

ACCLIMATIVE RESPONSE TO TEMPERATURE STRESS IN HighER PLANTS: APPROACHES OF GENE ENGINEERING FOR TEMPERATURE TOLERANCE, Koh I $\mathrm{l} a$

SAlt and Drought Stress Signal TRANDUCtion In Plants, Jian-Kang Zhu

THE LiPOXYGENASE PATHWAY, Ivo Feussner and Claus Wasternack

PLANT RESPONSES TO INSECT HERBIVORY: THE EMERGING

MOLECULAR ANALYSIS, André Kessler and Ian T. Baldwin

PHYTOCHROMES CONTROL PHOTOMORPHOGENESIS BY

DifFERENTIALLY REGULATED, INTERACTING SIGNALING

PATHWAYS IN HighER PLANTS, Ferenc Nagy and Eberhard Schäfer 
The Complex Fate of $\alpha$-Ketoacids, Brian P. Mooney, Jan A. Miernyk, and Douglas D. Randall

MoleCular Genetics of AuXin Signaling, Ottoline Leyser

Rice as A Model For Comparative GenOMics of Plants, Ko Shimamoto and Junko Kyozuka

ROOT GRAVITROPISM: AN EXPERIMENTAL TOOL TO INVESTIGATE Basic Cellular and Molecular Processes Underlying MECHANOSENSING AND SIGNAL TRANSMISSION IN PLANTS, K. Boonsirichai, C. Guan, R. Chen, and P. H. Masson

RUBISCO: STRUCTURE, REGULATORY INTERACTIONS, AND POSSIBILITIES FOR A BETTER ENZYME, Robert J. Spreitzer and Michael E. Salvucci

A New Moss Genetics: TARgeted Mutagenesis IN PHYSCOMITRELLA PATENS, Didier G. Schaefer

CompleX EVolution of Photosynthesis, Jin Xiong and Carl E. Bauer 503

Chlororespiration, Gilles Peltier and Laurent Cournac

STRUCTURE, DYNAMICS, AND ENERGETICS OF THE PRIMARY PHOTOCHEMISTRY OF PHOTOSYSTEM II OF OXYGENIC PHOTOSYNTHESIS, Bruce A. Diner and Fabrice Rappaport

INDEXES

Subject Index

Cumulative Index of Contributing Authors, Volumes 43-53

Cumulative Index of Chapter Titles, Volumes 43-53

\section{ERRATA}

An online log of corrections to Annual Review of Plant Biology chapters (if any, 1997 to the present) may be found at http://plant.annualreviews.org/ 